University of Konstanz

Department of Economics

\title{
Auditing, Consulting, and Audit Market Concentration
}

Christopher Bleibtreu and Ulrike Stefani

Working Paper Series

2011-28 


\title{
Auditing, Consulting, and Audit Market Concentration
}

\author{
Christopher Bleibtreu $^{1}$ and Ulrike Stefani ${ }^{2}$
}

August 2011

\begin{abstract}
In its recently published Green Paper, the European Commission 2010 discusses various methods to enhance the reliability of audits and to re-establish trust in the financial market. The Commission primarily focuses on increasing auditor independence and on reducing the high level of audit market concentration. Based on a model in the tradition of the circular market matching models introduced by Salop 1979, we show that prohibiting non-audit services as a measure intended to improve auditor independence can have counter-productive secondary effects on audit market concentration. In fact, our model demonstrates that incentives for independence and the structure of the audit market are simultaneously determined. Because market shares are endogenous in our model, it is not even clear that prohibiting non-audit services indeed increases an auditor's incentive to remain independent.
\end{abstract}

\section{Keywords}

Auditing, Audit Fees, Knowledge Spillovers, Audit Market Concentration, Auditor Independence

\section{JEL-Classification}

D43, L11, M42

\footnotetext{
${ }^{1}$ Department of Economics, Box D-142, 78467 Konstanz, Germany,

E-Mail: christopher.bleibtreu@uni-konstanz.de

${ }^{2}$ Department of Economics, Box D-142, 78467 Konstanz, Germany,

E-Mail: ulrike.stefani@uni-konstanz.de
} 


\section{Motivation}

Ever since the recent global financial crisis brought to light the urgent need to stabilize the financial system, legislators around the world have begun to implement far-reaching measures to tighten the regulation of the banking sector. In addition, there has been vigorous debate about the respective roles of central banks, supervisory bodies, and rating agencies. With regard to financial accounting, the discussion has mainly focused on the advantages and disadvantages of fair-value accounting in comparison to historical cost accounting. To date, the audit profession has not come under much fire, even though numerous financially distressed banks had received unqualified audit opinions.

In a recently published Green Paper, however, the European Commission 2010 has shifted its attention towards the role of auditing. In particular, the Commission calls into question the adequacy of the current legislative framework and puts several proposals for enhancing the efficacy of auditing up for discussion. The aim of the proposed measures is to enhance the contribution of auditing in the process of re-establishing trust and market confidence, which would in turn increase the stability of the financial markets.

The Commission primarily addresses two major issues: the independence of auditors and the structure of the audit market. To reinforce auditor independence, the Commission proposes several measures, including assigning the responsibility for appointing and remunerating an auditor to a third party rather than to the audited company itself, the mandatory rotation of audit firms, a limit on the proportion of fees an audit firm can earn from a single audit client in relation to its total audit revenues, and the reinforcement of rules that prevent auditors from offering non-audit services to their audit clients. With regard to the structure of the audit market, the Commission recognizes that there are now only a handful of global audit firms able to perform audits on large, complex companies and financial institutions. The Commission predicts that the collapse of one of these "systemic" audit firms could potentially impair the stability of the financial system. Thus, the Commission recommends the mandatory formation of audit firm consortia in which at least one non-systemic audit firm is involved in auditing large clients, the mandatory rotation of audit firms to introduce more dynamism and capacity into the audit market, the mandatory re-tendering of mandates after a fixed period, and the reduction of barriers to market entry for small audit firms. The measures the Commission discusses are neither new nor completely convincing, and there has been prolonged discussion about the arguments put forward. Until now, however, the topics of "auditor independence" and "market structure" have generally been discussed separately.

In the following paper, we show that prohibiting non-audit services as a measure intended to improve auditor independence can have counter-productive secondary effects on audit market concentration. Our arguments are based on an audit market model in the tradition of the circular market matching models introduced by Schmalensee 1978 and Salop 1979. We distinguish between generalist audit firms that can provide consulting and audit services to both large and small clients, and small audit firms specialized in auditing small corporations. We assume that, compared to small audit firms, large audit firms have higher fixed costs and higher costs for planning the audit process. Small audit firms, in turn, have higher costs per unit of auditing clients for which they are not perfectly specialized. We assume that knowledge spillovers flowing from non-audit to audit services reduce the costs incurred in planning the audit process.

Our results indicate that prohibiting the provision of non-audit services to audit clients has direct effects on the structure of the audit market. If there is no competition between large and small audit firms for small clients during the time before the prohibition becomes effective, a ban on providing consulting services to audit clients actually leads to a further increase in absolute market concentration (e.g., as measured by the concentration ratio). More precisely, we predict that the equilibrium number of large audit firms will decrease, because realizable 
total profits will decrease if the provision of non-audit services is prohibited. This effect on market structure is in direct contrast to the aims the Commission has outlined in its Green Paper. If, however, small and large audit firms effectively compete for small clients, our model predicts that a prohibition of consulting services would increase the number of small audit firms (because prohibiting large audit firms to offer non-audit services eliminates their cost advantages derived from knowledge spillovers and thus increases the small audit firms' competitiveness), but would still decrease the number of "systemic" suppliers. Thus, the effect that a prohibition of the joint supply of audit and non-audit services has on the equilibrium market structure depends on the cost structures of the small and large suppliers of audit services, and on the degree of competition for small audit clients. Our results also show that regulatory reforms that address auditor independence cannot be discussed without taking their effects on market structure into account.

The latter result is particularly important because the auditor's incentive to remain independent is determined by the economic importance of the respective client in comparison to the economic advantages the auditor derives from serving all other clients. Thus, independence is affected by the equilibrium number and size of audit firms, i.e., by the structure of the audit market. When we take the resulting equilibrium number of audit firms into account, we demonstrate that the effect of prohibiting non-audit services on the independence of large audit firms is not straightforward: If we take the relation between the profit contribution an audit firm can earn from one single large client and the sum of the profit contributions from all other clients as a surrogate for auditor independence, prohibition naturally leads to a loss of the profit contribution earned from providing consulting services (negative consulting effect), which should increase the auditor's incentives to remain independent. However, the consulting effect is partially offset by an increase in the profit contribution earned from auditing the large client (positive audit effect), which is caused by a decrease in the equilibrium number of large suppliers. Since the consulting effect exceeds the auditing effect, the net effect of the prohibition is negative, i.e., the large audit firm's incentive to remain independent increases. But a large audit firm's independence from a large client increases only if auditors that do not issue an unqualified opinion actually also lose the profit contribution derived from providing consulting services to that client; if we only look at the profit contribution from auditing, independence decreases as a result of the prohibition of non-audit services. Thus, our model shows that the assumption that prohibiting the joint supply of non-audit services improves auditor independence is at least questionable.

The paper is organized into three sections. In Section 2, we review the relevant literature. Section 3 presents our market matching model. In Section 4, we summarize our principal findings and derive conclusions regarding the Commission's proposal for audit market regulation.

\section{$2 \quad$ Literature}

To date, only a few analytical papers have directly addressed the effects of the joint supply of audit and non-audit services. Beck/Wu 2006, for example, focus on the trade-off between audit fees and audit quality. They present a nonstrategic, dynamic Bayesian model to analyze audit quality, which is measured as the precision of the auditor's posterior beliefs regarding client-specific characteristics. In their model, audit quality is affected by two components: Auditors learn from doing audits over time (learning effect), and auditors can perform nonaudit services that influence their clients' managerial decisions (business advisory effect). Thus, providing non-audit services enables the auditor to anticipate changes in their clients' business models. The results of Beck/Wu 2006 indicate that large professional fees can lead auditors to provide non-audit services that increase engagement risk and reduce audit quality. 
DeAngelo 1981 has put forward a different definition of audit quality, viewing it as the market-assessed joint probability that auditors will both discover and report material misstatements in their clients' accounting systems. Based on her model, DeAngelo 1981 argues that the ratio between the economic advantage auditors derive from one client ("quasi-rent") and the sum of the economic advantages they earn from providing services to all of their clients is crucial for auditor independence. The provision of non-audit services can increase the profit contribution derived from one specific client, and thus increase the economic advantage auditors put at risk if they deviate from an unqualified audit opinion.

In line with this argument, Beck et al. 1988 presented a model to analyze the relationship between non-audit services and auditor independence. They showed that the provision of recurring non-audit services that decrease the auditor's start-up costs for auditing a client can decrease the quasi-rent derived from that particular client, and thus reduce the threat to auditor independence. Non-recurring non-audit services, however, are predicted to increase the clientspecific quasi-rent only if knowledge spillovers reduce the ongoing costs for auditing the client. ${ }^{1}$ Although Beck et al. 1988 offer a detailed explanation of the conditions that must be fulfilled for non-audit services to increase a client-specific quasi-rent, the authors do not address the ratio of quasi-rents that is crucial for the potential impairment of auditor independence, because neither the behavior of other clients nor the effect of allowing or prohibiting non-audit services on the auditors' market shares is explicitly modeled. In the present paper, we analyze market shares and the equilibrium number of audit firms. Although our focus is not on auditor independence, based on our model the quasi-rent ratio (seen as an indicator for auditor independence) can be derived for situations in which providing consulting services is allowed, and compared to the ratio from a situation in which auditors do not perform nonaudit services. Thus, we are able to investigate whether a prohibition of the joint supply of audit and non-audit services indeed improves auditor independence.

The idea of applying a market matching model to the audit market has also been presented in papers by Chan 1999 and Simons/Zein 2011. To model the auditors decisions regarding the level of audit quality they want to supply (i.e., quality-related audit market segmentation), Simons/Zein 2011 adopt a linear market matching model based on Hotelling 1929. An interesting result of this paper is that improving the market position of mid-tier audit firms can lead to a decrease in overall audit quality. Chan 1999 uses a three-stage variant of the Hotelling 1929 spatial-competition model, taking into account auditors' start-up costs and thus relationship-specific economic interests. He focuses on auditors' decisions regarding their specialization with respect to client characteristics and on the economic implications of low-balling. However, Chan 1999 and Simons/Zein 2011 do not address the effects of nonaudit services.

\section{$3 \quad$ A Model of the Audit Market}

\subsection{Assumptions}

We use a circular market matching model inspired by Salop 1979 to analyze the interdependence between the joint supply of audit and consulting services and the structure of the audit market. We assume that the supply side of the audit market consists of two kinds of audit firms. In particular, we assume that there is a small number of large generalist audit firms, indexed by $i=1, \ldots, n$, and a large number of small specialized audit firms, indexed by $j=1, \ldots, m$. In line with empirical concentration studies, ${ }^{2}$ we assume that there are more small audit firms than large ones. ${ }^{3}$ Generalist audit firms employ a large number of audit staff with a variety of individual abilities and thus have a wide spectrum of professional knowledge at hand. In this way, large audit firms are able to provide a variety of audit and consulting 
services worldwide to all kinds of clients with varying audit-relevant characteristics. Specialized audit firms, in contrast, have only a small number of audit staff, and consequently the range of their professional competencies is limited. Therefore, we assume that specialists can provide audit services but not consulting services to their clients. The results of our analysis would not change if we assumed that specialists could provide consulting services in addition to audit services (to small clients only).

The demand side of our model is also made up of two groups, here based on the size of companies to be audited: a large number of small clients and a small number of large clients. We assume that small clients only demand 1 unit of audit services each, whereas large clients buy $\alpha>1$ units of audit services in addition to 1 unit of consulting services. ${ }^{4}$ Our results do not change qualitatively when all clients are assumed to demand consulting services. To simplify the analysis, we assume that large clients are restricted to buying audit and consulting services from the same supplier. Since we take into account knowledge spillovers from consulting to auditing and thus the cost savings arising from economies of scope, this demand behavior would also emerge endogenously. Particularly in the case of audit-related consulting services, the joint supply of the two services can also be observed in real-world business practice. Moreover, we assume that generalist audit firms do not compete with pure consulting firms to provide non-audit services. ${ }^{5}$

As in the model presented by Salop 1979, suppliers and consumers are uniformly distributed on a unit circle (see Figure 1). The position of a client on the circle describes the client's audit and consulting-specific characteristics, such as its complexity (e.g., number of reports to be made, industry diversification, number of business areas, geographic dispersion of operations, corporate structure, listing status, and accounting standard in use) and its risk (e.g., financial position, management incentives regarding earnings management, and quality of the internal control system). With regard to the distribution of clients on the unit circle, we consider a continuous case. The mass of small clients is normalized to 1 , and large clients have a mass of $0<\mu<1$. The position of an audit firm on the unit circle determines the correspondence between the audit firm's specialization and the client's characteristics.

Figure 1: Audit firms and clients on the unit circle

The cost structure of the audit firms is as follows: Every audit firm incurs some fixed costs that arise even if the audit firm does not provide services to any client. We assume the fixed costs of specialized audit firms, $c_{F}^{s}$, to be lower than the fixed costs of generalist audit firms, $c_{F}^{l}$, i.e., $c_{F}^{s}<c_{F}^{l}$. This assumption reflects the higher overhead costs of generalist audit firms employing a large number of audit staff. ${ }^{6}$ These fixed costs can also be interpreted as a market entry barrier.

In addition, audit firms incur some variable costs for auditing a certain client. We assume that an auditor's variable costs consist of a component dependent on the client's characteristics and of a component that is not affected by the client's characteristics.

Characteristic-independent audit costs reflect the costs associated with regulatory oversight of public company audits and the effort necessary to plan the audit process (e.g., expenses incurred to allocate audit staff to the audit firm's various clients, costs arising from the determination of the scope of system audits and from auditing particular cases, and costs arising from the effort of estimating the clients' inherent risk and control risk). In our model, characteristic-independent audit costs thus occur even in a situation in which auditor and client are at the same spot on the unit circle. An audit firm's cost for one unit of auditing a client with characteristics the auditor is perfectly specialized in is normalized to $c_{0}^{l}>0$ for generalist audit firms and to $c_{0}{ }^{s}=0$ for specialized audit firms. The assumption $c_{0}{ }^{l}>c_{0}{ }^{s}$ reflects the fact that large audit firms simply have more staff that must be assigned to different tasks. In addition, 
we assume that large audit firms have higher reputational and litigation risks than small audit firms, and must therefore exert more effort in planning the audit than small audit firms do. Since we assume that only large audit firms can audit large (listed) clients, large audit firms face more restrictive requirements from regulatory oversight and must cope with more demanding accounting and auditing standards than small suppliers do.

Characteristic-dependent audit costs, in contrast, are affected by the distance $x$ between the audit firm and the client's position on the unit circle. ${ }^{7}$ As mentioned above, this distance represents the difference between a client's characteristics and an auditor's main focus regarding these characteristics. Characteristic-dependent audit costs reflect the audit effort actually exerted in conducting the audit, given a certain predetermined level of assurance that clients' financial statements are free from material misstatement. We assume that the characteristicdependent audit costs increase linearly with the distance $x{ }^{8}$ Thus, the variable costs for auditing a small client located $x$ units away from the audit firm are $c_{0}{ }^{l}+c_{A}{ }^{l} \cdot x$ per unit of audit services for a generalist audit firm, and $c_{A}{ }^{s} \cdot x$ for a specialized audit firm (see Figure 2).

Figure 2: Characteristic-dependent costs for auditing a small client at location $x$

Because $c_{0}{ }^{l}>c_{0}{ }^{s}$, small audit firms have an advantage in auditing small clients matching or close to their own specialization (i.e., for which there is only a small distance between audit firm and client on the unit circle). Generalist audit firms, in contrast, have an advantage in auditing small clients with characteristics they are not explicitly specialized in, because we assume that $c_{A}{ }^{l}<c_{A}{ }^{s}$ holds (see Raghunandan et al. 2004). This cost relation accounts for the small audit firms' specialization on the one hand and the broader competencies of large audit firms on the other. In addition, this relation takes into account the large audit firms' capacity advantages, as their cost increase for auditing more clients is smaller than the cost increase for small audit firms. We do not, however, account for the possibility that providing services to clients with similar characteristics could lead to a reduction in fixed costs (e.g., as a result of the auditor's industry specialization; see Cairney/Young 2006 and Hogan/Jeter 1999).

We assume that only large audit firms have the capacities necessary to audit large clients. ${ }^{9}$ The variable costs for auditing a large client at distance $x$ are thus given by $\alpha \cdot\left(c_{0}{ }^{l}+c_{A}{ }^{l} \cdot x\right)$, as these clients demand $\alpha$ units of audit services.

For providing audit services, an arbitrary large or small audit firm $a=i, j$ demands an audit fee denoted by $f e e_{A}{ }^{a}(x)$. Thus, we allow for price discrimination based on the distance between client and audit firm. We do not explicitly model the empirical result that large audit firms, because of higher audit quality in comparison to small suppliers, better reputation, or a "deep pockets mentality", charge higher audit fees than small suppliers, ceteris paribus (see the meta-analysis conducted by Hay et al. 2006). However, inclusion of "Big X" pricepremiums that are fixed across clients would not alter our results, since additional fixed-fee components could be regarded as a reduction in the characteristic-independent variable audit costs.

In addition to audit services, each large client is assumed to also demand 1 unit of consulting services. As with the audit costs, we assume that a large audit firm's consulting costs depend on the locations of the audit firm and the client on the unit circle. An audit firm's costs for providing consulting services to a client located at the same spot on the unit circle are normalized to 0 . We denote the consulting costs for a client located $x$ units away from the audit firm by $c_{C} \cdot x$. If audit and consulting services are provided by the same audit firm, we refer to the combined fee an arbitrary large audit firm $i$ charges a large client as $f e e_{A l+C}{ }^{i}$. 
Large audit firms naturally earn additional profits from providing consulting services, which are evidently more profitable than audit services. In line with the arguments against the prohibition of the joint supply of audit and consulting services put forward by the auditing profession, we assume that offering consulting services additionally reduces audit costs. More specifically, we assume that knowledge spillovers from consulting to auditing decrease the characteristic-independent audit costs. In particular, we assume that the audit firm receives information about its client's business in the course of providing consulting services, and that this information eases the planning of the audit process (e.g., because the auditor learns about the actual inherent risk and the control risk of the client; see Beck/Wu 2006). If an audit firm provides consulting services for a large client located $x$ units away from its own location, audit costs per unit of audit services are thus reduced to $\gamma \cdot c_{0}{ }^{l}+c_{A}{ }^{l} \cdot x$, with $0<\gamma<1$.

The question of whether knowledge spillovers actually exist has received a great deal of attention in the empirical accounting literature. Most of the studies using a single-equation model with audit fees as a dependent and non-audit fees as an independent variable have obtained a positive relationship between non-audit fees and audit fees, ${ }^{10}$ which could either be the result of knowledge spillovers or of systematic differences between clients purchasing non-audit services and clients receiving audit services only. Tests based on audit fees, however, rely on the assumption that services are billed consistently with the "physical flow of knowledge" (Simunic 1984, p. 685), so the results of these studies might be contaminated by pricing policies and cross-subsidization between services. ${ }^{11}$ Since non-audit fees could be endogenous in the audit fee regression, an econometric test using single-equation models with audit fees (non-audit fees) as a dependent (independent) variable can result in biased coefficients. Thus, the significantly positive association between audit and non-audit fees documented in the literature could be the result of biased or inconsistent estimation of the non-audit fee coefficient induced by the use of endogenous variables in single-equation models. Whisenant et al. 2003 found that characteristics of clients, auditors, and the auditor-client relationship simultaneously determine audit and non-audit fees. ${ }^{12}$ In particular, Whisenant et al. 2003 were unable to detect a significant association between audit and non-audit fees using a simultaneous specification of the audit and non-audit fee system. ${ }^{13}$ One major additional problem in obtaining empirical evidence for economies of scope seems to be the specification of the non-audit fee model, since we do not have a good theoretical understanding of the production of consulting services, nor do we have sufficiently powerful instruments to estimate audit and non-audit fees. However, an adequate definition of the non-audit fee equation is particularly crucial if a simultaneous-equations specification is applied.

\subsection{Reference Situation I: A Market Consisting of Specialized Audit Firms Only}

As a starting point, we consider a market that consists solely of a constant number $m$ of small audit firms. By assumption, potential clients of the specialized audit firms must stem from the group of small clients that demand 1 unit of audit services each.

To derive the audit fees and an arbitrary audit firm's number of clients, we consider a random pair of similar audit firms. The similarity of these two suppliers is given by their smallest possible distance $1 / m$ on the unit circle. Assume that $x$ is some point on the unit circle located between audit firms $j$ and $j-1$ (i.e., we define $x$ to lie between 0 and $1 / m$ units away from audit firm $j$ ). A client is willing to buy audit services from a supplier $j$ located $x$ units away on the unit circle instead of from the second-nearest supplier $j-1$ located $1 / m-x$ units away only if the requested fee of audit firm $j, f e e_{A}{ }^{j}(x)$, is smaller than the fee of audit firm $j-1, f e e_{A}{ }^{j-1}(1 / m-x)$. Thus, audit firm $j$ wins the audit contract only if $f e e_{A}{ }^{j}(x) \leq f e e_{A}{ }^{j-1}(1 / m-x)$. However, it would only be profitable for audit firm $j$ to accept a 
client at location $x$ if the fee charged were higher than or equal to the corresponding audit costs, i.e., if $f e e_{A}{ }^{j}(x) \geq c_{A}{ }^{s} \cdot x$, or, equivalently, if $x \leq f e e_{A}{ }^{j}(x) / c_{A}{ }^{s}$. Analogously, it is profitable for audit firm $j-1$ to audit the client at location $x$ only if $f e e_{A}{ }^{j-1}(1 / m-x) \geq c_{A}{ }^{s} \cdot(1 / m-x)$, or if $(1 / m-x) \leq f e e_{A}{ }^{j-1}(1 / m-x) / c_{A}{ }^{s}$. Figure 3 graphs the costs for auditing an arbitrary small client in between two small audit firms.

Figure 3: Costs for auditing an arbitrary small client in between two small audit firms

In our model, the two audit firms compete for a client in a Bertrand competition by undercutting each other's audit fees. Thus, a client at position $x^{\prime}$ will accept an audit contract with audit firm $j$ instead of a contract with audit firm $j-1$ only if $f e e_{A}{ }^{j}\left(x^{\prime}\right) \leq f e e_{A}{ }^{j-1}\left(1 / m-x^{\prime}\right)$ or if $c_{A}{ }^{s} \cdot x^{\prime} \leq c_{A}{ }^{s} \cdot\left(1 / m-x^{\prime}\right)$ (i.e., if $x^{\prime} \leq 1 / m-x^{\prime}$, so the client is closer to audit firm $j$ than to audit firm $j-1)$. Thus, audit firm $j$ can set its audit fee to $f e e_{A}{ }^{j}\left(x^{\prime}\right)=c_{A}{ }^{s} \cdot\left(1 / m-x^{\prime}\right)$, which is the last competitive fee offer of audit firm $j-1$. Similarly, for a client located closer to audit firm $j-1$ than to audit firm $j$ at $x^{\prime \prime}$, so that $c_{A}{ }^{s} \cdot x^{\prime \prime} \geq c_{A}{ }^{s} \cdot\left(1 / m-x^{\prime \prime}\right)$ holds (i.e., $x^{\prime \prime} \geq$ $\left.1 / m-x^{\prime \prime}\right)$, audit firm $j-1$ wins the contract and charges a fee of $f e e_{A}{ }^{j-1}\left(1 / m-x^{\prime \prime}\right)=c_{A}{ }^{s} \cdot x^{\prime \prime}$.

The threshold for the apportionment of clients located in between two audit firms on the unit circle is found at location $\bar{x}=1 / 2 m$, as the two audit firms' costs for auditing a small client are identical at this spot, i.e., $c_{A}{ }^{s} \cdot \bar{x}=c_{A}{ }^{s} \cdot(1 / m-\bar{x})$. At this point exactly between the two audit firms, the audit fee is $f e e_{A}{ }^{j}(\bar{x})=c_{A}{ }^{s} / 2 m=f e e_{A}{ }^{j-1}(1 / m-\bar{x})$. Since we assume a continuous number of clients, we do not have to determine which of the two audit firms wins the audit contract with the client located exactly at point $\bar{x}$.

The maximum audit fee an audit firm $j$ can charge is the fee that the client located at the same spot on the unit circle as audit firm $j$ is willing to accept. The audit fee for this client is determined by the costs of the second-nearest audit firm $j-1$ (at a distance of $1 / m$ units) and is given by $f e e_{A}{ }^{j}(0)=c_{A}{ }^{s} / m$. As this reasoning holds for both directions on the unit circle, audit firm $j$ 's revenues from providing audit services to small clients, given a certain number $m$ of small audit firms, can be calculated as

$$
\Pi_{A}{ }^{j}=2 \cdot \frac{1}{2 m} \cdot\left[\frac{c_{A}{ }^{s}}{2 m}+\frac{1}{2}\left(\frac{c_{A}{ }^{s}}{m}-\frac{c_{A}{ }^{s}}{2 m}\right)\right]=\frac{3 \cdot c_{A}{ }^{s}}{(2 m)^{2}} .
$$

Figure 4 depicts these revenues graphically.

Figure 4: Small audit firms' revenues from providing audit services

In our model, every small client gets an audit contract. The restriction $x \leq f e e_{A}{ }^{j}(x) / c_{A}{ }^{s}$ for an audit contract to be profitable is always fulfilled, since the threshold company located $1 / 2 m$ units away from the two nearest audit firms on the unit circle is charged an audit fee of $f e e_{A}{ }^{j}(1 / 2 m)=c_{A}{ }^{s} / 2 m$. Thus, the profitability restriction $1 / 2 m \leq\left(c_{A}{ }^{s} / 2 m\right) / c_{A}{ }^{s}=1 / 2 m$ is always fulfilled. In addition, none of the audit firms has monopoly power at their spot on the unit circle, because the nearest other audit firm, $j-1$, has an incentive to audit this client for a fee of $f e e_{A}{ }^{j-1}(1 / m)=c_{A}{ }^{s} / m$. Thus, the audit firm located at the same spot as a client cannot charge a monopoly fee exceeding the costs of audit firm $j-1$. 
To calculate the profit contribution resulting from the provision of audit services, we must subtract the variable costs (i.e., the characteristic-independent costs, which are normalized to $c_{0}{ }^{s}=0$ for small audit firms, and the characteristic-dependent $\operatorname{costs} c_{A}{ }^{s} \cdot x$ ) from the revenues. The characteristic-dependent costs for a client located at the same spot on the unit circle as the audit firm are 0 . The costs for auditing the client at the greatest possible distance $(1 / 2 m)$ would be $c_{A}{ }^{s} / 2 m$. The calculation of the characteristic-dependent audit costs $C_{A}{ }^{j}$ of a small audit firm $j$ is analogous to the calculation of the revenues:

$$
C_{A}{ }^{j}=2 \cdot \frac{1}{2 m} \cdot \frac{1}{2} \frac{c_{A}{ }^{s}}{2 m}=\frac{c_{A}{ }^{s}}{(2 m)^{2}} .
$$

The profit contribution audit firm $j$ earns can thus be calculated as

$$
\pi_{A}{ }^{j}=\Pi_{A}{ }^{j}-C_{A}{ }^{j}=\frac{c_{A}{ }^{s}}{2 m^{2}} .
$$

An illustration of this profit contribution can be found in Figure 5.

Figure 5: Small audit firms' profit contribution earned from providing audit services

To derive the equilibrium number of small audit firms in a market without large suppliers, we must take the fixed $\operatorname{costs} c_{F}{ }^{s}$ into account. If we abstract from additional market entry barriers, audit firms will enter the market if they can earn positive profits, i.e., if $\pi_{A}{ }^{j}-c_{F}{ }^{s}>0$. If profits are negative, small audit firms will drop out. Thus, in market equilibrium, the condition $\pi_{A}{ }^{j}-c_{F}{ }^{s}=0$ or $c_{A}{ }^{s} / 2 m^{2}=c_{F}{ }^{s}$ must be fulfilled. The equilibrium number $m^{*}$ of small suppliers is therefore

$$
m^{*}=\sqrt{\frac{c_{A}{ }^{s}}{2 \cdot c_{F}{ }^{s}}} \cdot 14
$$

Obviously, the equilibrium number of small audit firms decreases with the fixed $\operatorname{costs} c_{F}{ }^{s}$, and increases with the characteristic-dependent audit costs per unit of "distance" $x, c_{A}{ }^{s}$.

\subsection{Reference Situation II: A Market Consisting of Generalist Audit Firms Only}

\subsubsection{Large Audit Firms Provide Only Audit Services}

In the following section, we consider a situation in which the audit market consists only of $n$ large audit firms. Large audit firms differ from small suppliers in two audit-related aspects: First, only large audit firms are capable of auditing large clients. Second, compared to specialized audit firms, large audit firms have an advantage regarding characteristic-dependent audit costs per unit of "distance" $x$ (because $c_{A}{ }^{l}<c_{A}{ }^{s}$ ), but operate at a disadvantage in terms of characteristic-independent audit costs $\left(c_{0}{ }^{l}>c_{0}{ }^{s}=0\right)$. In the first step, we assume that large audit firms provide audit services but not consulting services.

Analogous to the analysis of an audit market consisting purely of small audit firms, we consider two similar large audit firms, $i$ and $i-1$. We assume that $x$ is some point on the unit circle that lies between audit firms $i$ and $i-1$. Taking the positive characteristic-independent audit costs $c_{0}{ }^{l}$ of a large audit firm into account, it is profitable for audit firm $i$ to audit a (small or large) client located $x$ units away only if $f e e_{A}^{i}(x) \geq c_{0}^{l}+c_{A}^{l} \cdot x$. For the secondnearest audit firm $i-1$, providing audit services to a client at distance $1 / n-x$ is advanta- 
geous only if $f e e_{A}{ }^{i-1}(1 / n-x) \geq c_{0}{ }^{l}+c_{A}{ }^{l} \cdot(1 / n-x)$. Thus, audit firm $i$ rather than audit firm $i-1$ will audit a client at position $x^{\prime}$ if $c_{0}{ }^{l}+c_{A}{ }^{l} \cdot x^{\prime} \leq c_{0}{ }^{l}+c_{A}{ }^{l} \cdot\left(1 / n-x^{\prime}\right)$, i.e., if audit firm $i$ is closer to that client than audit firm $i-1$ is $\left(x^{\prime} \leq 1 / n-x^{\prime}\right)$. For this client, audit firm $i$ can charge an audit fee of $f e e_{A}{ }^{i}\left(x^{\prime}\right)=c_{0}{ }^{l}+c_{A}{ }^{l} \cdot\left(1 / n-x^{\prime}\right)$. If, in contrast, a client is located $x^{\prime \prime}$ units away from audit firm $i$, and $x^{\prime \prime} \geq 1 / n-x^{\prime \prime}$, then audit firm $i-1$ can realize a fee of $f e e_{A}{ }^{i-1}\left(1 / n-x^{\prime \prime}\right)$ $=c_{0}^{l}+c_{A}^{l} \cdot x^{\prime \prime}$, because $c_{0}^{l}+c_{A}^{l} \cdot x^{\prime \prime} \geq c_{0}^{l}+c_{A}^{l} \cdot\left(1 / n-x^{\prime \prime}\right)$.

As in the case of a market consisting solely of small audit firms, the threshold for the division of clients between two large audit firms is given by $\bar{x}=1 / 2 n$. The audit fee for small clients located at this point is given by $f e e_{A}{ }^{i}(\bar{x})=c_{0}{ }^{l}+c_{A}{ }^{l} / 2 n$, and again the fee charged for a client situated at exactly the same spot as the audit firm is $f e e_{A}^{i}(0)=c_{0}^{l}+c_{A}^{l} / n$. These arguments lead to the revenues a large audit firm $i$ can realize from auditing small clients:

$$
\Pi_{A s}{ }^{i}=2 \cdot \frac{1}{2 n} \cdot\left[c_{0}{ }^{l}+\frac{c_{A}{ }^{l}}{2 n}+\frac{1}{2}\left(\left(c_{0}{ }^{l}+\frac{c_{A}{ }^{l}}{n}\right)-\left(c_{0}{ }^{l}+\frac{c_{A}{ }^{l}}{2 n}\right)\right)\right]=\frac{c_{0}{ }^{l}}{n}+\frac{3 \cdot c_{A}{ }^{l}}{(2 n)^{2}} .
$$

Considering the large clients' demand for auditing $\alpha$ as well as their mass $\mu$ results in the revenue an arbitrary large audit firm $i$ can earn from auditing large clients:

$$
\Pi_{A l}{ }^{i}=(\mu \cdot \alpha) \cdot\left(\frac{c_{0}{ }^{l}}{n}+\frac{3 \cdot c_{A}{ }^{l}}{(2 n)^{2}}\right) .
$$

Again, every client gets an audit contract, and no audit firm can exercise monopoly power. Summing up both partial revenues yields the large audit firm $i$ 's revenues from providing audit services:

$$
\Pi_{A}{ }^{i}=\Pi_{A s}{ }^{i}+\Pi_{A l}{ }^{i}=(1+\mu \cdot \alpha) \cdot\left(\frac{c_{0}{ }^{l}}{n}+\frac{3 \cdot c_{A}{ }^{l}}{(2 n)^{2}}\right) .
$$

To calculate the profit contribution of auditing, variable costs (i.e., $c_{0}{ }^{l}>0$ and $c_{A}{ }^{l} \cdot x$ ) must be subtracted from the revenues. The costs for auditing the clients at the smallest and the largest distance on the unit circle are $c_{0}{ }^{l}$ and $c_{0}{ }^{l}+c_{A}{ }^{l} / 2 n$, respectively. Thus, the variable costs of a large audit firm $i$ for auditing small and large clients are given by

$$
\begin{aligned}
& C_{A s}^{i}=2 \cdot \frac{1}{2 n} \cdot\left[c_{0}{ }^{l}+\frac{1}{2}\left(\left(c_{0}{ }^{l}+\frac{c_{A}{ }^{l}}{2 n}\right)-c_{0}{ }^{l}\right)\right]=\frac{c_{0}{ }^{l}}{n}+\frac{c_{A}{ }^{l}}{(2 n)^{2}} \text { and } \\
& C_{A l}{ }^{i}=(\mu \cdot \alpha)\left(\frac{c_{0}{ }^{l}}{n}+\frac{c_{A}{ }^{l}}{(2 n)^{2}}\right) .
\end{aligned}
$$

In sum, the variable costs of audit firm $i$ are

$$
C_{A}{ }^{i}=C_{A s}{ }^{i}+C_{A l}{ }^{i}=(1+\mu \cdot \alpha)\left(\frac{c_{0}{ }^{l}}{n}+\frac{c_{A}{ }^{l}}{(2 n)^{2}}\right) .
$$

Subtracting the variable audit costs from the revenues results in the profit contribution of a large audit firm $i$ :

$$
\pi_{A}{ }^{i}=\Pi_{A}{ }^{i}-C_{A}{ }^{i}=(1+\mu \cdot \alpha) \cdot \frac{c_{A}{ }^{l}}{2 n^{2}} .
$$

The equilibrium number of suppliers in a market consisting only of large audit firms that do not provide consulting services is given by 


$$
n_{A}^{*}=\sqrt{(1+\mu \cdot \alpha) \cdot \frac{c_{A}{ }^{l}}{2 \cdot c_{F}{ }^{l}}} .
$$

Similar to the situation of a market of small audit firms, the equilibrium number of large audit firms increases with the characteristic-dependent $\operatorname{costs} c_{A}{ }^{l}$, and decreases with the fixed costs $c_{F}{ }^{l}$. In addition, the equilibrium number of large audit firms increases with the mass of large clients, $\mu$, and their demand for auditing, $\alpha$. The characteristic-independent costs $c_{0}{ }^{l}$ have no effect on the equilibrium number of audit firms, since they are identical across audit firms and fully shifted to the clients.

In the beginning, we assumed that there were more specialized audit firms than generalists. Comparison of our results for the separate markets (equations (4) and (11)) indicates that this assumption can also evolve endogenously. The condition $m^{*}>n^{*}$ is fulfilled if the ratio between characteristic-dependent audit costs and fixed audit costs for specialized audit firms is larger than the respective weighted cost ratio for generalists:

$$
\frac{c_{A}{ }^{s}}{c_{F}{ }^{s}}>\frac{(1+\mu \cdot \alpha) \cdot c_{A}{ }^{l}}{c_{F}{ }^{l}} .
$$

The above inequality holds if the small audit firms' characteristic-dependent costs $c_{A}{ }^{s}$ (fixed audit $\operatorname{costs} c_{F}{ }^{s}$ ) are relatively high (low), and if the large audit firms' characteristic-dependent costs $c_{A}{ }^{l}$ (fixed audit costs $c_{F}{ }^{l}$ ) are relatively low (high). These conditions are in line with our initial assumptions $c_{F}{ }^{s}<c_{F}{ }^{l}$ and $c_{A}{ }^{s}>c_{A}{ }^{l}$. In addition, inequality (12) - necessary for $m^{*}>n^{*}$ to hold - requires that this cost effect not be offset by a comparatively large number of large clients, $\mu$, or by an excessive demand for audit services, $\alpha$.

\subsubsection{Large Audit Firms Provide Consulting Services To Their Audit Clients}

In contrast to the preceding section, we now consider a situation in which generalist audit firms can also provide consulting services to their large audit clients. We assume that consulting services create spillover effects on the costs incurred for audits of large clients, i.e., the characteristic-independent audit costs for large clients who buy consulting services are reduced to $\alpha \cdot\left(\gamma \cdot c_{0}{ }^{l}+c_{A}{ }^{l} \cdot x\right)$. The costs for auditing small clients, however, are assumed to be unaffected, since small clients do not demand consulting services in our model.

As before, the consulting costs for a client located $x$ units away from the audit firm are $c_{C} \cdot x$. Given these assumptions, the respective fees a client at the threshold $\bar{x}=1 / 2 n$ and a client located at the same spot as the audit firm must pay to receive audit and consulting services from audit firm $i$ are given by

$$
\begin{aligned}
& f e e_{A l+C}{ }^{i}(1 / 2 n)=\alpha \cdot\left(\gamma \cdot c_{0}^{l}+c_{A}^{l} / 2 n\right)+c_{C} / 2 n \text { and } \\
& f e e_{A l+C}{ }^{i}(0)=\alpha \cdot\left(\gamma \cdot c_{0}^{l}+c_{A}^{l} / n\right)+c_{C} / n .
\end{aligned}
$$

From providing auditing and consulting services to large clients, audit firm $i$ earns revenues of

$$
\Pi_{A l+C}^{i}=(\mu \cdot \alpha) \cdot\left(\frac{\gamma \cdot c_{0}{ }^{l}}{n}+\frac{3 \cdot c_{A}{ }^{l}}{(2 n)^{2}}\right)+\mu \cdot \frac{3 \cdot c_{C}}{(2 n)^{2}} .
$$

The costs for providing auditing and consulting services for large clients are 


$$
C_{A l+C}{ }^{i}=(\mu \cdot \alpha) \cdot\left(\frac{\gamma \cdot c_{0}{ }^{l}}{n}+\frac{c_{A}{ }^{l}}{(2 n)^{2}}\right)+\mu \cdot \frac{c_{C}}{(2 n)^{2}},
$$

and the profit contribution from providing auditing and consulting services to large clients is

$$
\pi_{A l+C}^{i}=\Pi_{A l+C}{ }^{i}-C_{A l+C}{ }^{i}=(\mu \cdot \alpha) \cdot \frac{c_{A}{ }^{l}}{2 n^{2}}+\mu \cdot \frac{c_{C}}{2 n^{2}} .
$$

The profit contribution from auditing small clients is similar to the expression stated above in equation (10):

$$
\pi_{A s}{ }^{i}=\Pi_{A s}{ }^{i}-C_{A s}{ }^{i}=\frac{c_{A}{ }^{l}}{2 n^{2}} .
$$

The total profit contribution of a large audit firm thus is given by

$$
\pi_{A+C}{ }^{i}=\pi_{A l+C}{ }^{i}+\pi_{A s}{ }^{i}=(1+\mu \cdot \alpha) \cdot \frac{c_{A}{ }^{l}}{2 n^{2}}+\mu \cdot \frac{c_{C}}{2 n^{2}} .
$$

The equilibrium number of large audit firms follows from the zero-profit condition $\left(\pi_{A+C}^{i}=c_{F}^{l}\right)$ :

$$
n_{A+C}^{*}=\sqrt{(1+\mu \cdot \alpha) \cdot \frac{c_{A}{ }^{l}}{2 \cdot c_{F}{ }^{l}}+\mu \cdot \frac{c_{C}}{2 \cdot c_{F}{ }^{l}}} .
$$

Thus, in comparison to a situation in which the joint supply of audit and consulting services is prohibited, the equilibrium number of large audit firms is strictly larger if generalists can also provide consulting services to large clients, i.e., $n_{A+C}{ }^{*}>n_{A}{ }^{*}$ (see equation (11)). The reasoning behind this result is that consulting services are quite profitable for audit firms. ${ }^{15}$ The additional direct profit contribution $\pi_{C}{ }^{i}=\mu \cdot\left(c_{C} / 2 n^{2}\right)$ earned from consulting services attracts more suppliers to enter the market, i.e., the number of audit firms increases. Interestingly, the fact that knowledge spillovers reduce the characteristic-independent costs $c_{0}^{l}$ for auditing large clients has no effect on the equilibrium number of audit firms, since these costs are fully shifted to the clients.

We can derive qualitatively similar results if we assume that providing consulting services for a large client also reduces the costs for auditing a small client located at the same spot as the large client. However, we must consider the fact that the profit contribution realizable for small clients affects the last fee offer an audit firm is willing to accept in order to secure an audit and consulting contract with a large client. Specifically, it might be profitable to make a fee offer below actual costs for providing services to large clients. Because of spillover effects, this pricing strategy can yield a profitable contract with a small client at the same spot. Not surprisingly, we find that the profit contribution derived in this scenario is even larger than in the case in which only the audit costs of the large client actually buying consulting services are reduced. The optimal number of audit firms increases with the profit contribution, because fixed costs are assumed to be constant across the scenarios we consider. Thus, the equilibrium number of generalist audit firms is larger in the case of knowledge spillovers also to small clients, as compared to a situation in which consulting services reduce only the costs for auditing the client actually buying the consulting services.

To sum up, large audit firms can increase their profit contribution from auditing by providing consulting services, which increases the equilibrium number of audit firms. Therefore, prohibiting the joint supply of audit and non-audit services reduces audit firms' profit contributions, and thus reduces the optimal number of suppliers. Our result thus has important policy implications for a market in which only generalist audit firms are present.

Concentration studies show that the market segment of listed companies of some national audit markets are indeed characterized by a situation in which (almost) exclusively large audit firms are present. The European Commission considers auditors of internationally listed 
firms, and notably of financial institutions, as "systemic"; maintaining the number of "systemic" audit firms, in turn, is one of the major objectives the Commission seeks to achieve through the implementation of the measures outlined in its Green Paper. If, however, the joint provision of audit and consulting services is abolished in the market setting we have just analyzed, our model predicts a decrease in the number of large audit firms. Thus, the Commission's goals of decreasing audit market concentration and of improving auditor independence interact. ${ }^{16}$ The prohibition of the joint supply of audit and consulting services therefore might be counter-productive if a high level of market concentration (defined as a low number of suppliers active in a market segment, or a high value of the concentration ratio) is viewed as undesirable.

In addition, it is not clear whether a prohibition of the joint supply of auditing and consulting indeed strengthens an auditor's incentives to remain independent. The ratio between the profit contribution a generalist audit firm earns from auditing (and consulting) one specific client, $p c^{i}(x)$, to the total profit contribution $\pi^{i}\left(n^{*}\right)$ a generalist can realize can be considered an indicator for auditor independence. Since this ratio's maximum value is obtained for a client located at exactly the same spot as the audit firm, we focus on $r(0)=p c^{i}(0) / \pi^{i}\left(n^{*}\right)$. Since the zero-profit condition $\pi^{i}\left(n^{*}\right)=c_{F}{ }^{l}$ must be fulfilled, $\pi^{i}\left(n^{*}\right)$ remains constant across our scenarios if we take into account the optimal number of audit firms. Thus, only the clientspecific profit contribution $p c^{i}(0)$ is relevant. Assuming that knowledge spillovers only affect the large client actually buying consulting services, the profit contribution derived from auditing the most profitable small client, $p c^{i}(0)$, is given by

$$
p c_{A s}{ }^{i}(0)=c_{0}{ }^{l}+c_{A}{ }^{l} / n *-c_{0}{ }^{l}=c_{A}{ }^{l} / n^{*} \text {. }
$$

Prohibiting non-audit services would lead to a decrease in the optimal number of large suppliers, which would increase the individual profit contribution $p c_{A s}{ }^{i}(0)$, i.e., weaken the auditor's incentive to remain independent.

For the most profitable large client, however, the profit contributions from auditing (and consulting services) are given by

$$
\begin{aligned}
& p c_{A l+C}{ }^{i}(0)=\frac{\alpha \cdot c_{A}^{l}}{n_{A+C} *}+\frac{c_{c}}{n_{A+C} *} \text { in the case of auditing and consulting, and } \\
& p c_{A l}^{i}(0)=\frac{\alpha \cdot c_{A}{ }^{l}}{n_{A} *} \text { if only auditing is allowed. }
\end{aligned}
$$

Here, prohibition of non-audit services would eliminate the second term in equation (21) (negative consulting effect), which would, of course, strengthen auditor independence; nevertheless, the first term in (22) is larger than in (21), since $n_{A} *<n_{A+C} *$, i.e., the profit contribution derived from auditing the most profitable large client is higher if only auditing services are provided, as compared to a situation in which the joint supply of the two services is allowed (positive audit effect). Thus, the effect of a prohibition of non-audit services on auditor independence depends on whether auditors who do not issue an unqualified audit opinion on a client's financial statements also lose the associated consulting contract. If this is the case, a prohibition increases independence from large clients, since $p c_{A l+C}{ }^{i}(0)>p c_{A l}{ }^{i}(0)$ holds. If, in contrast, only the audit contract is lost, a prohibition decreases auditor independence. ${ }^{17}$ Thus, there might be counter-productive secondary effects on auditor independence from small (and possibly also large) clients if we take the effects on the market structure into account. 


\subsubsection{Large Audit Firms Provide Consulting Services, But Not To Their Audit Clients}

In the preceding section, we have shown that a prohibition of the joint supply of audit and consulting services is predicted to decrease the equilibrium number of large audit firms. One argument against a decrease in the number of suppliers is that audit firms might circumvent the loss of profitable consulting contracts by providing non-audit services to companies other than their audit clients. Figure 6 illustrates the reasoning we apply to derive a large audit firm's resulting profit contribution.

Figure 6: Large audit firms' profit contribution earned from providing audit and consulting services to various clients

Assume that audit firm $i$ provides consulting services to the clients the audit firm is specialized in, i.e., to clients within a distance of $x \leq 1 / 2 n$ on both sides of the unit circle. As a result of the prohibition, audit firm $i$ does not audit clients in this region, but only clients at distance $x>1 / 2 n$. Audit firm $i$ therefore competes with audit firm $i-2(i+2)$ for audit contracts with clients at distance $x>1 / 2 n$ to the "left" ("right") of audit firm $i$; because audit firm $i-1(i+1)$ provides consulting services to these clients, $i-1(i+1)$ is not allowed to compete for audit contracts in this region.

The costs audit firm $i$ incurs by auditing clients at distance $1 / 2 n(1 / n)$ are given by $\alpha \cdot\left(c_{0}{ }^{l}+c_{A}{ }^{l} / 2 n\right)\left(\alpha \cdot\left(c_{0}{ }^{l}+c_{A}{ }^{l} / n\right)\right)$, since there are no knowledge spillovers from consulting for one client to auditing a different client. The audit costs of competitor $i-2(i+2)$ determine the fee audit firm $i$ can charge:

$$
\begin{aligned}
& f e e_{A}{ }^{i}(1 / 2 n)=\alpha \cdot\left(c_{0}{ }^{l}+c_{A}{ }^{l} \cdot(3 / 2 n)\right) \text { and } \\
& f e e_{A}{ }^{i}(1 / n)=\alpha \cdot\left(c_{0}{ }^{l}+c_{A}{ }^{l} / n\right) .
\end{aligned}
$$

Thus, the profit contribution for auditing clients at distances of $1 / 2 n<x \leq 1 / n$ is the same as in the case without consulting, i.e.,

$$
\pi_{A}{ }^{j}=\mu \cdot \alpha \cdot \frac{c_{A}{ }^{l}}{2 n^{2}} .
$$

Since the total profit contribution from auditing and consulting is unaffected by the prohibition against the joint supply of the two services if audit firms re-arrange their audit and consulting contracts, the equilibrium number of audit firms is the same as in the case in which audit firms are allowed to provide both services to their clients. Audit fees, however, increase due to the prohibition by $\alpha \cdot\left(c_{A}{ }^{l} / 2 n\right)$, on average. ${ }^{18}$

\subsection{A Joint Market Consisting of Specialized And Generalist Audit Firms}

\subsubsection{Motivation}

Up to this point, we have investigated two different partial markets consisting of either only small or only large audit firms. The assumption of segmented audit markets has practical relevance for national audit markets that are characterized by high values of the concentration ratio. Simplistically, these markets can be divided into a group of large audit firms providing audit (and non-audit) services primarily to large corporations and a group of small suppliers providing audit services predominantly to small clients. ${ }^{19}$ For other audit markets, however, the allocation of clients among audit firm types is less clear-cut. In less concentrated markets, there might be competition between large and small audit firms, at least for smaller listed cor- 
porations or for larger unlisted firms. ${ }^{20}$ In the next step of our analysis, we thus investigate a joint audit market consisting of both large and small audit firms. As above, small audit firms are assumed to audit small clients only. Thus, in our model there is competition for small clients between the two types of audit firms; for auditing and consulting services for large clients, however, there is competition only within the group of large suppliers.

\subsubsection{Large Audit Firms Do Not Compete Against Small Audit Firms For Providing Audit Services To Small Clients}

In the first step, we assume that - prior to the prohibition against providing both kinds of services to audit clients - large audit firms cannot effectively compete against small audit firms, because their characteristic-independent audit costs are large compared to those of their smaller competitors. Moreover, we assume that providing consulting services only affects the costs for auditing the client actually buying consulting services. Thus, we assume that the market is effectively separated into large and small suppliers.

In the reference situation with only small audit firms, the highest fee a specialized audit firm could charge was the fee for auditing a small client located at exactly the same spot on the unit circle, i.e., $f e e_{A}{ }^{j}(0)=c_{A}{ }^{s} / m^{*}$. Inserting the equilibrium number of firms $m^{*}$ (see equation (4)) leads to $f e e_{A}{ }^{j}(0)=\sqrt{2 \cdot c_{A}{ }^{s} \cdot c_{F}{ }^{s}}$. If the small audit firm's maximum fee is lower than an arbitrary large audit firm $i$ 's minimum costs incurred for auditing a small client (i.e., $\left.c_{A s}{ }^{i}(0)=c_{0}^{l}\right)$, no large audit firm would win an audit contract with a small client. If condition $c_{0}{ }^{l}>\sqrt{2 \cdot c_{A}{ }^{s} \cdot c_{F}{ }^{s}}$ is fulfilled, the $m^{*}$ specialized audit firms would provide audit services to all of the small clients, charging an average audit fee of $\overline{f e e_{A s}}=(3 / 4) \cdot\left(c_{A}{ }^{s} / m^{*}\right)$ $=3 / 4 \cdot \sqrt{2 \cdot c_{F}{ }^{s}} \cdot \sqrt{c_{A}{ }^{s}}$. This average audit fee equals the total audit fees small clients pay, since the mass of small clients is normalized to 1 .

Prohibiting the joint supply of audit and consulting services in this scenario can only affect the market segment of large firms. The equilibrium number of large audit firms would decrease from $n_{A l+C}{ }^{*}=\sqrt{(\mu \cdot \alpha) \cdot \frac{c_{A}{ }^{l}}{2 \cdot c_{F}{ }^{l}}+\mu \cdot \frac{c_{C}}{2 \cdot c_{F}{ }^{l}}}$ to $n_{A}{ }^{*}=\sqrt{(\mu \cdot \alpha) \cdot \frac{c_{A}{ }^{l}}{2 \cdot c_{F}{ }^{l}}}$. The derivation of the equilibrium number of large audit firms is analogous to that for equations (11) and (19), taking into account that the large audit firms do not audit small clients (the index $A l$ indicates that solely large clients are audited). In our model, a decrease in the number of large audit firms is equivalent to an increase in absolute market concentration, since the number of small audit firms remains constant. This effect is exactly the opposite of what the European Commission had envisioned for the strategy of prohibiting consulting services.

The average fee large clients have to pay for the combined services of auditing and consulting is $\overline{f e e_{A l+C}}=\alpha \cdot\left(\gamma \cdot c_{0}{ }^{l}+\frac{3 \cdot c_{A}{ }^{l}}{4 n_{A l+C}{ }^{*}}\right)+\frac{3 \cdot c_{C}}{4 n_{A l+C}{ }^{*}}=\gamma \cdot \alpha \cdot c_{0}{ }^{l}+3 / 4 \cdot \sqrt{2 \cdot c_{F}{ }^{l}} \cdot \sqrt{\alpha / \mu \cdot c_{A}{ }^{l}+1 / \mu \cdot c_{C}}$, whereas the average audit fee when only auditing is allowed is $\overline{f e e_{A l}}=\alpha \cdot\left(c_{0}{ }^{l}+\frac{3 \cdot c_{A}{ }^{l}}{4 n_{A}{ }^{*}}\right)=$ $\alpha \cdot c_{0}{ }^{l}+3 / 4 \cdot \sqrt{2 \cdot c_{F}{ }^{l}} \cdot \sqrt{\alpha / \mu \cdot c_{A}{ }^{l}}$. In line with the arguments put forward by the auditing profession (and their clients), average audit fees would thus increase, at least for large clients (we compare the fee component related to audit services, i.e., the first term in the average combined fee, $\overline{f e e_{A l+C}}$, in the case in which consulting is allowed, with the average audit fee after 
the prohibition of consulting services is enacted, $\overline{f e e_{A l}}$ ). The total fees paid in the two cases are $\mu \cdot \overline{f e e_{A l+C}}$ and $\mu \cdot \overline{f e e_{A l}}$. To compare the total fee paid in the two scenarios, one could assume a separate market for consulting services for the case in which audit firms are not allowed to provide consulting services to their audit clients. If we stick to the same linear consulting cost pattern as in the preceding analysis, there would be an equilibrium number of consulting firms of $o^{*}=\sqrt{\mu \cdot \frac{c_{C}{ }^{C}}{2 \cdot c_{F}{ }^{C}}}$, where $c_{F}{ }^{C}$ are the fixed costs and $c_{C}{ }^{C}$ the characteristicdependent costs of firms offering consulting services only. Average consulting fees would be $\overline{f e e_{C}}=\frac{3 \cdot c_{C}{ }^{C}}{4 o^{*}}=3 / 4 \cdot \sqrt{2 \cdot c_{F}{ }^{C}} \cdot \sqrt{1 / \mu \cdot c_{C}{ }^{C}}$. It becomes clear that whether the overall fee paid increases or decreases is dependent on the cost structure of firms offering only consulting services. If we assume that consulting firms' fixed costs and characteristic-dependent costs are comparable to those of audit firms, i.e., $c_{F}{ }^{C} \approx c_{F}{ }^{l}$ and $c_{C}{ }^{C} \approx c_{C}$, consulting fees would also increase as a result of the prohibition on providing combined services. ${ }^{21}$ Remember that we have assumed that non-audit services are supplied by large audit firms only, i.e., there are no consulting firms. Thus, we can assume that firms offering only consulting services would have higher costs than audit firms, and thus there would be a cost increase for auditing as a result of the prohibition against the joint supply of audit and non-audit services.

To sum up, the prohibition against consulting services reduces the number of large audit firms and increases the audit fees large clients have to pay, but does not affect competition among small audit firms. This result for the joint market is analogous to the comparison based on separate markets, ${ }^{22}$ and is not surprising, since the markets are effectively separated due to the higher costs large audit firms incur. Separation would, however, also evolve endogenously and not simply by assumption. We investigate the more interesting case of a joint audit market in the next section.

\subsubsection{There Is Competition Between Large And Small Audit Firms For Providing Audit Services To Small Clients}

In this section, we assume parameter constellations that ensure competition between large and small audit firms for small clients during the time period before the prohibition on supplying both services goes into effect. First, for a given number of audit firms, we derive the number of clients that audit firms can contract with and the audit fees paid in the cases with and without consulting (short-term effect). As there is no direct short-term effect of prohibiting consulting services on the market for auditing small clients (if consulting only affects the costs for auditing clients actually receiving consulting services), we assume in the following analysis that there are knowledge spillovers also to similar small clients. Second, we investigate how the equilibrium number of audit firms changes, i.e., how a prohibition on consulting services affects market structure in the long run.

We assume an initial market with a number of large audit firms $n$ and small audit firms $m$. In addition, we presume that both large and small audit firms are uniformly distributed on the unit circle. Thus, the distance between an arbitrary large audit firm $i$ and the nearest large audit firm $i-1$ is again $1 / n$, and the distance between two small audit firms is $1 / \mathrm{m}$. The small audit firm with the shortest distance to the large audit firm $i$ in one direction of the unit circle is located somewhere between the two extreme distances 0 and $1 / \mathrm{m}$. A distance of 0 means that the nearest small audit firm is located at exactly the same spot on the unit circle as audit firm $i$, and thus the second-nearest small audit firm's position on the unit circle is at a distance of $1 / m$. A distance of $1 / 2 m$ means that the large audit firm $i$ is located exactly in 
between two small audit firms. A distance of slightly less than $1 / m$ means that on one side of the unit circle, the next small audit firm's position is only very slightly shifted from the large audit firm's location, so that the distance to the next firm on the other side of the circle is nearly $1 / m$. We label the distance between the large audit firm $i$ and the nearest small audit firm $j$ as $d \quad(0 \leq d<1 / m)$.

Due to reasons of symmetry, large audit firms get audit and consulting contracts with large clients within a distance of $1 / 2 n$ in each direction of the unit circle. Within this distance, characteristic-independent costs for both large and small clients are given by $\gamma \cdot c_{0}^{l}$ per unit of audit service.

The lowest audit fee a specialized audit firm can charge if it effectively competes with the nearest small audit firm applies to a small client located at a distance of $1 / 2 m$, i.e., $f e e_{A}{ }^{j}(1 / 2 m)=c_{A}{ }^{s} / 2 m$. If $c_{0}^{l}<c_{A}{ }^{s} / 2 m$ holds (e.g., if the costs a large audit firm incurs for auditing a client located at exactly the same spot are lower than the audit fee the small audit firm at the largest possible distance $1 / 2 m$ charges), large audit firms can win audit contracts with small clients, even if consulting services are prohibited. If we make the more restrictive assumption $c_{0}^{l}+c_{A}^{l} / 2 n<c_{A}{ }^{s} / 2 m$, we can ensure that small audit firms always compete with their nearest large audit firm. Thus, in the following analysis we consider a situation in which the prohibition of consulting services does not lead to separation of the joint market of small and large audit firms. If, however, knowledge spillovers from consulting are very high, i.e., $\gamma$ is very low, a prohibition on consulting could lead to separate audit markets for large and small clients (see Figure 7). For this effect to occur, the conditions $\gamma \cdot c_{0}{ }^{l}+c_{A}{ }^{l} / 2 n<c_{A}{ }^{s} / 2 m$ and $c_{0}^{l}>c_{A}{ }^{s} / 2 m$ must be fulfilled.

Figure 7: Cost structures of small and large audit firms if a prohibition on providing consulting services leads to separation of the audit markets

With consulting, the costs of the large audit firm $i$ to audit a small client at exactly the same spot on the unit circle are given by $c_{A s}{ }^{i}(0)=\gamma \cdot c_{0}{ }^{l}$, whereas the nearest large competitor's costs would be $c_{A s}{ }^{i-1}(1 / n)=c_{0}{ }^{l}+c_{A}{ }^{l} / n$. These costs are always larger than $i$ 's costs. The costs of the nearest small audit firm $j$ are $c_{A s}{ }^{j}(d)=c_{A}{ }^{s} \cdot d$. Audit firm $i$ effectively competes with audit firm $j$ for the audit contract with the small client located at exactly the same spot as audit firm $i$ if $c_{A}{ }^{s} \cdot d<c_{0}{ }^{l}+c_{A}{ }^{l} / n$. Otherwise, $i$ competes with the nearest other large audit firm $j+1$ (see Figure 8).

Figure 8: Cost structures of small and large audit firms

If $c_{A s}{ }^{i}(0)=\gamma \cdot c_{0}{ }^{l}<c_{A}{ }^{s} \cdot d=c_{A s}{ }^{j}(d)$, the large audit firm $i$ wins the contract with the small client at exactly the same spot as audit firm $i$ and can charge a fee of $\min \left\{c_{A}{ }^{s} \cdot d ; c_{0}{ }^{l}+c_{A}{ }^{l} / n\right\}$. Given the assumption $c_{A}{ }^{s} \cdot d<c_{0}{ }^{l}+c_{A}{ }^{l} / 2 n$, the large audit firm $i$ can charge an audit fee of $f e e^{i}(0)=c_{A}{ }^{s} \cdot d$ to the client at the same spot on the unit circle. ${ }^{23}$ The threshold at which the large audit firm $i$ 's costs are higher than the costs of the small audit firm $j$ can be derived from $\left.c_{A s}{ }^{i} \overline{x^{0}}\right)=\gamma \cdot c_{0}{ }^{l}+c_{A}{ }^{l} \cdot \overline{x^{0}} \geq c_{A}{ }^{s} \cdot\left(d-\overline{x^{0}}\right)=c_{A s}{ }^{j}\left(d-\overline{x^{0}}\right)$, i.e., $\overline{x^{0}} \geq\left(c_{A}{ }^{s} \cdot d-\gamma \cdot c_{0}{ }^{l}\right) /\left(c_{A}{ }^{s}+c_{A}{ }^{l}\right)$. If the distance between the large audit firm $i$ and a potential 
client exceeds this threshold, the nearest small audit firm $j$ wins the contract with the small client and can charge the large audit firm $i$ 's costs as an audit fee. The threshold at which the large audit firm $i$ 's costs are lower than the small audit firm $j$ 's costs can similarly be derived from $c_{A s}{ }^{i}\left(\underline{x^{0}}\right)=\gamma \cdot c_{0}{ }^{l}+c_{A}{ }^{l} \cdot \underline{x^{0}} \leq c_{A}{ }^{s} \cdot\left(\underline{x^{0}}-d\right)=c_{A s}{ }^{j}\left(\underline{x^{0}}-d\right)$ and is given by $\underline{x^{0}} \geq\left(c_{A}{ }^{s} \cdot d+\gamma \cdot c_{0}{ }^{l}\right) /\left(c_{A}{ }^{s}-c_{A}{ }^{l}\right)$. If the large audit firm $i$ effectively competes with the small audit firm $j$, audit firm $i$ wins the contracts with small clients if the distance exceeds this threshold. Due to the small clients' mass of 1, the number of clients of the small audit firm $j$ can be calculated by subtracting these two thresholds:

$$
\underline{x^{0}}-\overline{x^{0}}=2 \cdot c_{A}{ }^{s} \cdot \frac{d \cdot c_{A}{ }^{l}+\gamma \cdot c_{0}{ }^{l}}{\left(c_{A}{ }^{s}\right)^{2}-\left(c_{A}{ }^{l}\right)^{2}} .
$$

If the joint supply of audit and non-audit services is prohibited, in the short run the number of clients of the small audit firm $j$ would increase to

$$
2 \cdot c_{A}{ }^{s} \cdot \frac{d \cdot c_{A}{ }^{l}+c_{0}{ }^{l}}{\left(c_{A}{ }^{s}\right)^{2}-\left(c_{A}{ }^{l}\right)^{2}},
$$

i.e., $\Delta^{j}=2 \cdot c_{A}{ }^{s} \cdot(1-\gamma) \cdot c_{0}{ }^{l} /\left[\left(c_{A}{ }^{s}\right)^{2}-\left(c_{A}{ }^{l}\right)^{2}\right]$ small clients shift from the large audit firm $i$ to the small rival $j$.

For some arbitrary small audit firm $j-t$ at a distance larger than that of the small audit firm $j$ (see Figure 9), which effectively competes with the large audit firm $i$, one can generalize the threshold at which audit firm $i$ 's costs exceed audit firm $j-t$ 's costs by solving $c_{A s}{ }^{i}\left(\overline{x^{t}}\right)=\gamma \cdot c_{0}{ }^{l}+c_{A}{ }^{l} \cdot \overline{x^{t}} \geq c_{A}{ }^{s} \cdot\left(t / m+d-\overline{x^{t}}\right)=c_{A s}{ }^{j}\left(t / m+d-\overline{x^{t}}\right):$

$$
\overline{x^{t}}>\frac{(t / m+d) \cdot c_{A}{ }^{s}-\gamma \cdot c_{0}{ }^{l}}{c_{A}{ }^{s}+c_{A}{ }^{l}} \text {. }
$$

If $i$ and $j-t$ effectively compete, $j-t$ wins the consulting contracts with small clients and can charge a fee equal to audit firm $i$ 's costs. Similarly, one can compute the general threshold at which audit firm $i$ 's costs for auditing small clients are smaller than the costs of some arbitrary small audit firm $j-t$ by solving $c_{A s}{ }^{i}\left(\underline{x^{t}}\right)=\gamma \cdot c_{0}{ }^{l}+c_{A}{ }^{l} \cdot \underline{x}^{t} \leq c_{A}{ }^{s} \cdot\left(\underline{x^{t}}-t / m-d\right)$ $=c_{A s}^{j}\left(\underline{x^{0}}-t / m-d\right):$

$$
\underline{x^{t}}>\frac{(t / m+d) \cdot c_{A}{ }^{s}+\gamma \cdot c_{0}^{l}}{c_{A}{ }^{s}-c_{A}{ }^{l}} .
$$

Figure 9: Contracting region of audit firm $j-t$ with $t=1$

The difference between these thresholds gives the number of small clients for an arbitrary small audit firm $j-t$ that effectively competes with the nearest large audit firm $i$ :

$$
\underline{x}^{t}-\overline{x^{t}}=2 \cdot c_{A}{ }^{s} \cdot \frac{(t / m+d) \cdot c_{A}{ }^{l}+\gamma \cdot c_{0}{ }^{l}}{\left(c_{A}{ }^{s}\right)^{2}-\left(c_{A}{ }^{l}\right)^{2}} .
$$

A prohibition on consulting would, in the short run, result in a number of clients given by

$$
2 \cdot c_{A}{ }^{s} \cdot \frac{(t / m+d) \cdot c_{A}{ }^{l}+c_{0}{ }^{l}}{\left(c_{A}{ }^{s}\right)^{2}-\left(c_{A}{ }^{l}\right)^{2}}
$$


and thus to $\Delta^{j-t}=2 \cdot c_{A}{ }^{s} \cdot(1-\gamma) \cdot c_{0}{ }^{l} /\left[\left(c_{A}{ }^{s}\right)^{2}-\left(c_{A}{ }^{l}\right)^{2}\right]$ more clients for any arbitrary small audit firm $j-t$ that effectively competes with the large audit firm $i$. Thus, the increase in the number of clients due to a prohibition on consulting services is identical for each small audit firm.

An arbitrary small audit firm $j-t$ 's costs when consulting is not prohibited are given by

$$
\begin{aligned}
& C_{A s+C s}^{j-t}=\frac{1}{2} \cdot\left(\underline{x^{t}}-t / m-d\right) \cdot c_{A}{ }^{s} \cdot\left(\underline{x^{t}}-t / m-d\right)+\frac{1}{2} \cdot\left(t / m+d-\overline{x^{t}}\right) \cdot c_{A}{ }^{s} \cdot\left(t / m+d-\overline{x^{t}}\right) \\
& =\frac{1}{2} \cdot c_{A}{ }^{s}\left[\left(\underline{x^{t}}-t / m-d\right)^{2}+\left(t / m+d-\overline{x^{t}}\right)^{2}\right]=\left[\left(c_{A}{ }^{s}\right)^{3}+\left(c_{A}{ }^{l}\right)^{2} \cdot c_{A}{ }^{s}\right] \cdot \frac{\left((t / m+d) \cdot c_{A}{ }^{l}+\gamma \cdot c_{0}^{l}\right)^{2}}{\left(\left(c_{A}{ }^{s}\right)^{2}-\left(c_{A}{ }^{l}\right)^{2}\right)^{2}} .
\end{aligned}
$$

The large audit firm $i$ 's costs, and thus the revenues of audit firm $j-t$ within this region, are given by

$$
\begin{aligned}
& \Pi_{A s+C s}{ }^{j-t}=\left(\underline{x^{t}}-\overline{x^{t}}\right) \cdot\left[\gamma \cdot c_{0}{ }^{l}+c_{A}{ }^{l} \cdot \overline{x^{t}}+\frac{1}{2}\left[\gamma \cdot c_{0}{ }^{l}+c_{A}{ }^{l} \cdot \underline{x^{t}}-\left(\gamma \cdot c_{0}{ }^{l}+c_{A}{ }^{l} \cdot \overline{x^{t}}\right)\right]\right] \\
& =\left(c_{A}{ }^{s}\right)^{2} \cdot \frac{\left((t / m+d) \cdot c_{A}{ }^{l}+\gamma \cdot c_{0}{ }^{l}\right)^{2}}{\left(c_{A}{ }^{s}\right)^{2}-\left(c_{A}{ }^{l}\right)^{2}} \cdot\left[\frac{2 \cdot c_{A}{ }^{s}}{\left(c_{A}{ }^{s}\right)^{2}-\left(c_{A}{ }^{l}\right)^{2}}\right]=2\left(c_{A}^{s}\right)^{3} \cdot \frac{\left((t / m+d) \cdot c_{A}{ }^{l}+\gamma \cdot c_{0}^{l}\right)^{2}}{\left(\left(c_{A}^{s}\right)^{2}-\left(c_{A}{ }^{l}\right)^{2}\right)^{2}} .
\end{aligned}
$$

Subtracting the costs from the revenues leads to a profit contribution of

$$
\begin{aligned}
& \pi_{A s+C s}{ }^{j-t}=\Pi_{A s+C s}{ }^{j-t}-C_{A s+C s}{ }^{j-t} \\
& =2\left(c_{A}^{s}\right)^{3} \cdot \frac{\left((t / m+d) \cdot c_{A}^{l}+\gamma \cdot c_{0}^{l}\right)^{2}}{\left(\left(c_{A}^{s}\right)^{2}-\left(c_{A}^{l}\right)^{2}\right)^{2}}-\left[\left(c_{A}{ }^{s}\right)^{3}+\left(c_{A}{ }^{l}\right)^{2} \cdot c_{A}{ }^{s}\right] \cdot \frac{\left((t / m+d) \cdot c_{A}{ }^{l}+\gamma \cdot c_{0}{ }^{l}\right)^{2}}{\left(\left(c_{A}{ }^{s}\right)^{2}-\left(c_{A}{ }^{l}\right)^{2}\right)^{2}} \\
& =c_{A}{ }^{s} \cdot \frac{\left((t / m+d) \cdot c_{A}{ }^{l}+\gamma \cdot c_{0}{ }^{l}\right)^{2}}{\left(c_{A}{ }^{s}\right)^{2}-\left(c_{A}{ }^{l}\right)^{2}}>0 .
\end{aligned}
$$

A prohibition on consulting would lead to a similar result with $c_{0}{ }^{l}$ instead of $\gamma \cdot c_{0}{ }^{l}$, i.e.,

$$
\pi_{A s}{ }^{j-t}=\Pi_{A s}{ }^{j-t}-C_{A s}{ }^{j-t}=c_{A}{ }^{s} \cdot \frac{\left((t / m+d) \cdot c_{A}{ }^{l}+c_{0}{ }^{l}\right)^{2}}{\left(c_{A}{ }^{s}\right)^{2}-\left(c_{A}{ }^{l}\right)^{2}}>\pi_{A s+C s}{ }^{j-t} .
$$

This result holds for small audit firms $j-t$ that effectively only compete with the large audit firm $i$. Dependent on the shifted positions of large and small audit firms as well as on the relative number of small and large firms, a similar result holds for the small client located at the margin between the two large audit firms $i$ and $i-1$.

Thus, it is clear that prohibiting consulting services in the short run leads to an increased number of clients for small audit firms and also to increased revenues. The large audit firms, in contrast, lose clients to their small competitors, and they additionally lose the revenues from consulting for large clients. ${ }^{24}$ Because the small audit firms' profit contributions depend on their position relative to their nearest largest competitor (i.e., $\partial \pi_{A s}{ }^{j-t} / \partial t>0$ ), we cannot use the zero-profit constraint to calculate a new specific market equilibrium. However, taking into account the increased profit contributions of the small audit firms and the decline in large audit firms' profit contributions (which are also dependent on the ratio between the profit contribution from consulting and the profit contribution from auditing), we predict that in the long run, more small and fewer large audit firms will be active in the market for auditing small clients. This development leads to higher average audit fees for large clients. Even 
though there are more small audit firms, the audit fees of small clients will also increase, because the large audit firms' costs increase and thus small suppliers can charge higher fees.

\section{Conclusion}

In the aftermath of the recent financial crisis, the European Commission is seeking to improve the independence and reliability of audit firms in order to contribute to the stabilization of the financial system. In its recently published Green Paper, the European Commission suggests a two-pillar policy: First, the Commission points to the need to further increase auditor independence, and proposes a prohibition on the provision of non-audit services to audit clients as one possible way of achieving this goal. Simultaneously, the Commission is concerned about the high level of supplier concentration in most of the national audit markets within the European Union, and thus suggests methods of increasing the market position of second-tier audit firms. In the present paper, we show that the prohibition of the joint supply of audit and nonaudit services might have adverse effects on audit market concentration. This interrelation between these two focal issues on the Commission's agenda was not addressed in the Green Paper.

Our findings are based on a circular market matching model in the tradition of Salop 1979. We first investigated separate markets in which only large generalist audit firms or small specialized audit firms were active. In this scenario, our model predicted that the prohibition on supplying audit clients with non-audit services would decrease the number of large audit firms active in the market. The reasoning behind our findings is that a prohibition of the joint supply of audit and non-audit services increases audit costs. Given a certain amount of fixed costs, the reduced profit contribution large audit firms can earn in a pure audit market decreases the optimal number of suppliers. Since the number of corporations to be audited is constant, and we preclude competition between large and small audit firms, a decrease in the number of generalists is in line with an increase in audit market concentration.

Second, we investigated a market setting in which small and large audit firms competed to audit small clients. Given certain cost parameters, a prohibition of non-audit services could lead to a segmentation of the audit market, i.e., to the elimination of competition between large and small audit firms for small clients. This effect occurs if the knowledge spillovers from consulting are very high. If competition between large and small suppliers for small clients is still existent even after the prohibition, our model predicts that a prohibition of nonaudit services would create a relatively disadvantageous situation for large audit firms. Thus, the small audit firms' number of audit clients would increase, whereas the large audit firms would lose audit clients as well as profitable consulting contracts. Consequently, the number of large audit firms would decrease, while the number of small audit firms as well as their revenues would increase.

Our results indicate that the prohibition on supplying non-audit services to audit clients has secondary effects on the structure of the audit market. Thus, auditor independence and market concentration cannot be treated separately. However, whether the prohibition of non-audit services increases or decreases market concentration depends on the cost structures of small and large audit firms as well as on the degree of competition for small audit clients. Further detailed empirical studies of the national audit markets are necessary in order to provide support for arguments for or against the joint provision of audit and non-audit services. 


\section{Remarks}

1 See Ewert 1990, p. 197ff., Dopuch 1988, and Graham 1988 for a critique.

2 See, for example, General Accounting Office 2008 for the US, Ewert/London Economics 2006 for Europe, and Stefani 2006, Bigus/Zimmermann 2008, Petersen/Zwirner 2008, Köhler et al. 2010, and Quick/Sattler $2011 \mathrm{~b}$ for Germany.

3 We derive the conditions that must be fulfilled for the assumption $m>n$ to emerge endogenously below.

4 Our results from analyzing fee data from Switzerland and the USA show that clients of the (three and four) respective market leaders indeed demanded considerably more non-audit services than clients of the small audit firms. For the years 2002 to 2009 , we observed an average ratio between non-audit fees and audit fees in Switzerland and in the USA of $30.57 \%$ and $21.67 \%$ for clients of non-Big X audit firms, whereas this ratio was $67.84 \%$ and $35.55 \%$ for clients of Big X auditors.

The question of whether competition in the consulting market affects competition in the market for audit services is not the focus of this paper (for a formal analysis of this argument, see $\mathrm{Wu} 2006$ ).

6 The large audit firms' higher number of partners and assistants also contributes to the increased costs associated with acquiring and retaining audit staff and the higher expenses incurred for professional training. Chang et al. 2008 found empirical evidence that the number of training hours of partners and assistants is higher in big firms compared to middle-sized and small audit firms.

7 Based on data for US audits performed by an international public accounting firm, O'Keefe et al. 1994 found that client characteristics explain more than $80 \%$ of the cross-sectional variation in the quantity of professional labor input. Measures for the client characteristics used in this study (client size, complexity, and risk) were similar to those used in prior audit pricing studies. Fee studies also indicate that the characteristics of the client and the auditor-client relationship account for a large degree of the variance in audit fees (for a meta-analysis of the audit fee studies, see Hay et al. 2006).

The results we obtain would be qualitatively similar if we assumed a concave or a convex cost function.

9 Not only do small accounting firms face severe challenges in obtaining audit contracts from large clients, but it also seems that they are not very interested in serving this market segment (see General Accounting Office 2008). In addition, there is empirical evidence that the choice of the auditor depends on client characteristics (see Knechel et al. 2008).

10 See Simunic 1984, Simon 1985, DeBerg et al. 1991, and Bell et al. 2001 (US); Butterworth/Houghton 1995 and Craswell/Francis 1999 (Australia); and Ezzamel et al. 1996 (UK). Palmrose 1986, however, documented a positive relationship between audit fees charged by one supplier and non-audit fees paid to a different supplier that did not perform the audit, which contradicts the argument for knowledge spillovers.

11 Using data on audit staff hours, O'Keefe et al. 1994 did not find evidence of knowledge spillovers from management consulting and/or tax consulting to audit services. Davis et al. 1993 found a weakly significant positive relationship between tax services and different audit effort measures and between accounting-related consulting services and audit hours weighted by billing-rate ratios. If additional effort is required for audits of clients who also purchase non-audit services and the demand for auditing is inelastic (see Beck et al. 1988, p. 52-54), these results do not support the existence of audit production efficiencies arising from knowledge spillovers.

12 Antle et al. 2006 also have used a simultaneous-equations specification to estimate audit and non-audit fee models, finding evidence consistent with the existence of knowledge spillovers. Their result thus stands in opposition to the findings of Whisenant et al. 2003. Their fee models, however, might be mis-specified, since important variables measuring audit effort are not included.

13 Moreover, they showed that the significant coefficient of audit fees in a single-equation model with non-audit fees as a dependent variable (as documented in DeBerg et al. 1991, Barkess/Simnett 1994, and Craswell 1999 ) is also sensitive to simultaneous-equations bias.

14 In fact, numbers of audit firms between $m^{*} / 2$ and $m^{*}$ would also be possible equilibria if we considered a sequential market entry decision. Since we do not focus on the auditors' specialization decision, in the following sections we only consider the number of audit firms for which the zero-profit condition is fulfilled.

15 Anecdotal evidence suggests that the profession is seriously affected by decreasing hourly rates for auditing, which is seen as a springboard for attracting clients to buy higher-margin non-audit services (see, for example, Göggelmann 2010). The reasoning for "dumping pricing" is related to the overcapacities of audit firms (see o.V. 2009). There is, however, also evidence indicating that the decrease in revenues from non-audit services caused by the implementation of regulatory restrictions is being offset by a substantial increase in audit fees and in higher profit margins for audit services (see Weil 2004, Weil 2005, and Gullapalli 2005). 
16 Based on an empirical study, Quick/Sattler $2011 \mathrm{~b}$ make a similar argument regarding the interrelation between restricting the fee an audit firm is allowed to earn from a single audit client to a certain percentage (also viewed as a possible means to increase auditor independence) and the level of audit market concentration.

17 Khurana/Raman 2006 and Quick/Warming-Rasmussen 2009, for example, document the fact that addressees of financial reports perceive auditor independence to be impaired if auditing and consulting services are acquired from the same supplier, and Frankel et al. 2002 report a positive relationship between non-audit fees and the magnitude of discretionary accruals. Larcker/Richardson 2004 and Lim/Tan 2008, in contrast, observe that audit quality increases with the level of non-audit services, and Jenkins/Krawczyk 2001 find a favorable effect on perceived auditor independence in appearance (or no effect). Quick/Sattler 2011a demonstrate that attestation services and tax consulting services do not significantly affect earnings management, whereas consulting services from the category "miscellaneous" impair the quality of financial statements.

18 The qualitative results of our analysis do not change if audit firm $i$ audits clients it is specialized in and provides consulting services to clients outside this region: The profit contribution from consulting would not change, but the average consulting fees would increase by $c_{C} / 2 n$. Which of these cases is more costly for the clients depends on the relation between $\alpha \cdot c_{A}{ }^{l}$ and $c_{C}$.

19 From fiscal years 2002 to 2009, the three largest audit firms (KPMG, PricewaterhouseCoopers, and Ernst \& Young) audited on average $86 \%$ of listed corporations headquartered in Switzerland (not including financial institutions and real estate or insurance companies; data from Thomson One, Audit Analytics, and from annual reports). Thus, the Swiss audit market can serve as an example of a separated audit market.

20 Between 2002 and 2009, the largest four audit firms in the USA (KPMG, PricewaterhouseCoopers, Ernst \& Young, and Deloitte) provided audit services to only $56 \%$ of the listed companies headquartered in the USA, on average (data from Thomson One, Audit Analytics, and from annual reports). Thus, small audit firms had a non-negligible market share even in the market for listed companies, at least if the number of clients is used as a measure of calculating the concentration ratio.

21 This result, however, is straightforward, since we did not assume that audit firms incur additional fixed costs for providing consulting services to their clients.

22 For the case in which consulting also affects the costs for auditing small clients that are similar to the large clients consuming consulting services, our results are unaffected if the more restrictive restriction $\gamma \cdot c_{0}^{l}>\sqrt{2 \cdot c_{A}^{s} \cdot c_{F}^{s}}$ is fulfilled.

23 If the assumption does not hold because the number of large audit firms $n$ is sufficiently high and $c_{0}^{l}$ is sufficiently low, the large audit firm $i$ effectively competes with the nearest other large audit firm $i-1$ and could charge a fee of $f e e^{i}(0)=c_{0}{ }^{l}+c_{A}^{l} / n$.

24 A similar result holds for the case in which not all small audit firms in between two large audit firms effectively compete with the large audit firms. If small audit firms in a relatively large distance to the nearest large audit firm compete with each other, these small audit firms can be investigated as in Reference Situation I. The analysis of the audit firms relatively near to the large audit firms' positions is the same as described in this section. 
Figures

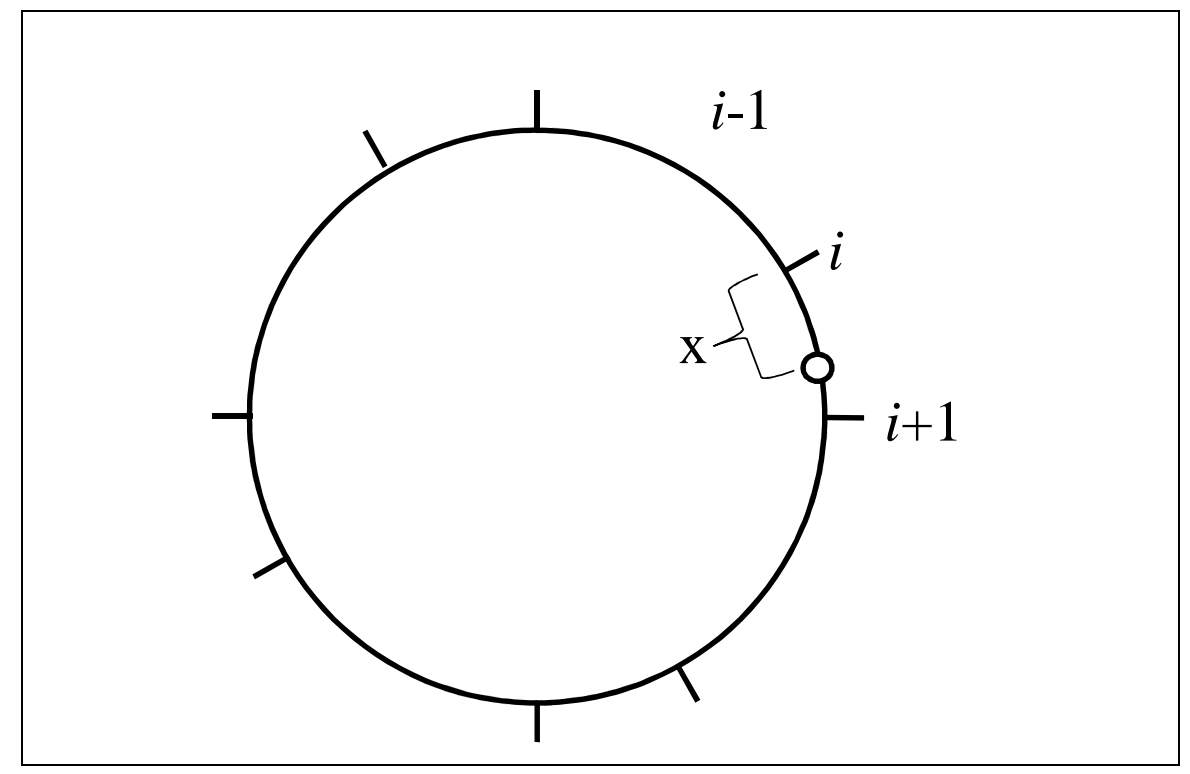

Figure 1: Audit firms and clients on the unit circle 
Distance between two audit firms and client

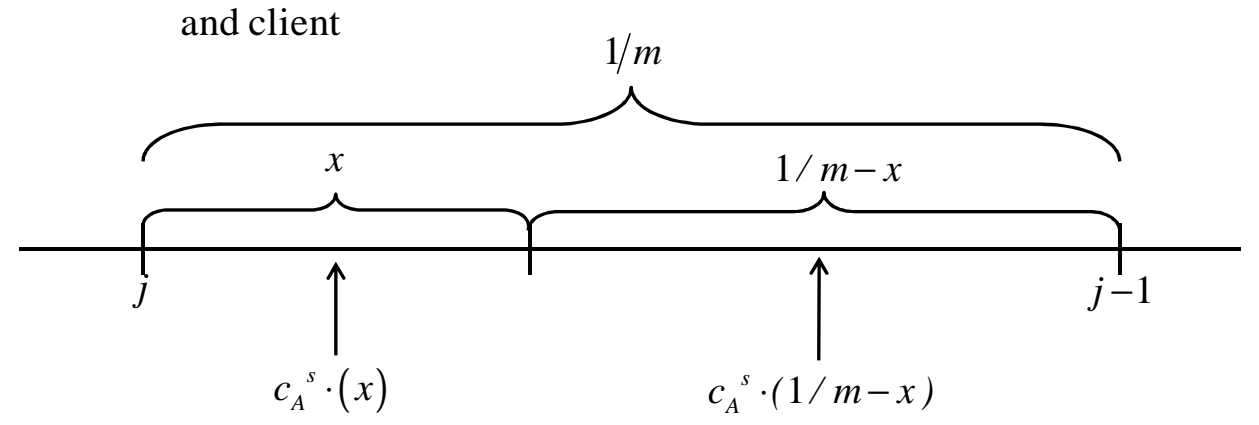

Characteristic-dependent audit costs

Figure 2: Characteristic-dependent costs for auditing a small client at location $x$ 


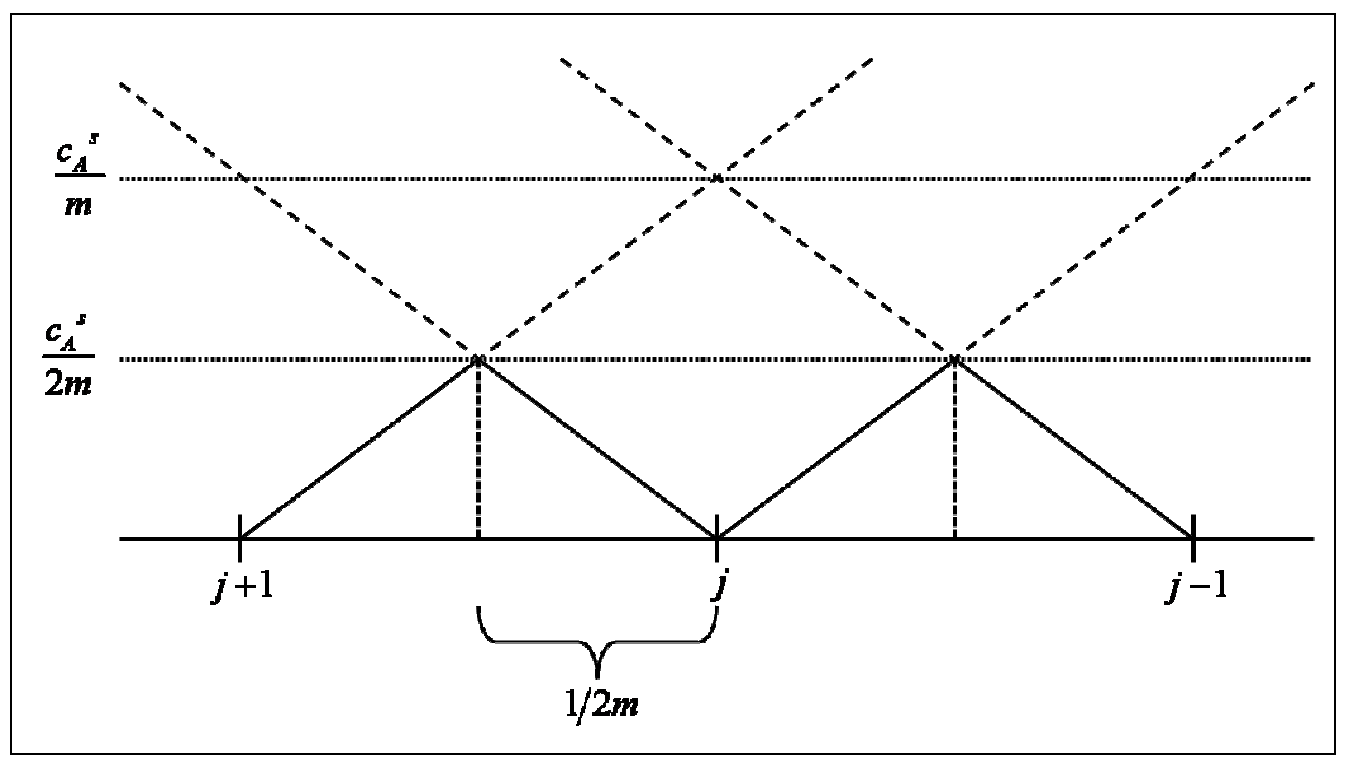

Figure 3: Costs for auditing an arbitrary small client in between two small audit firms 


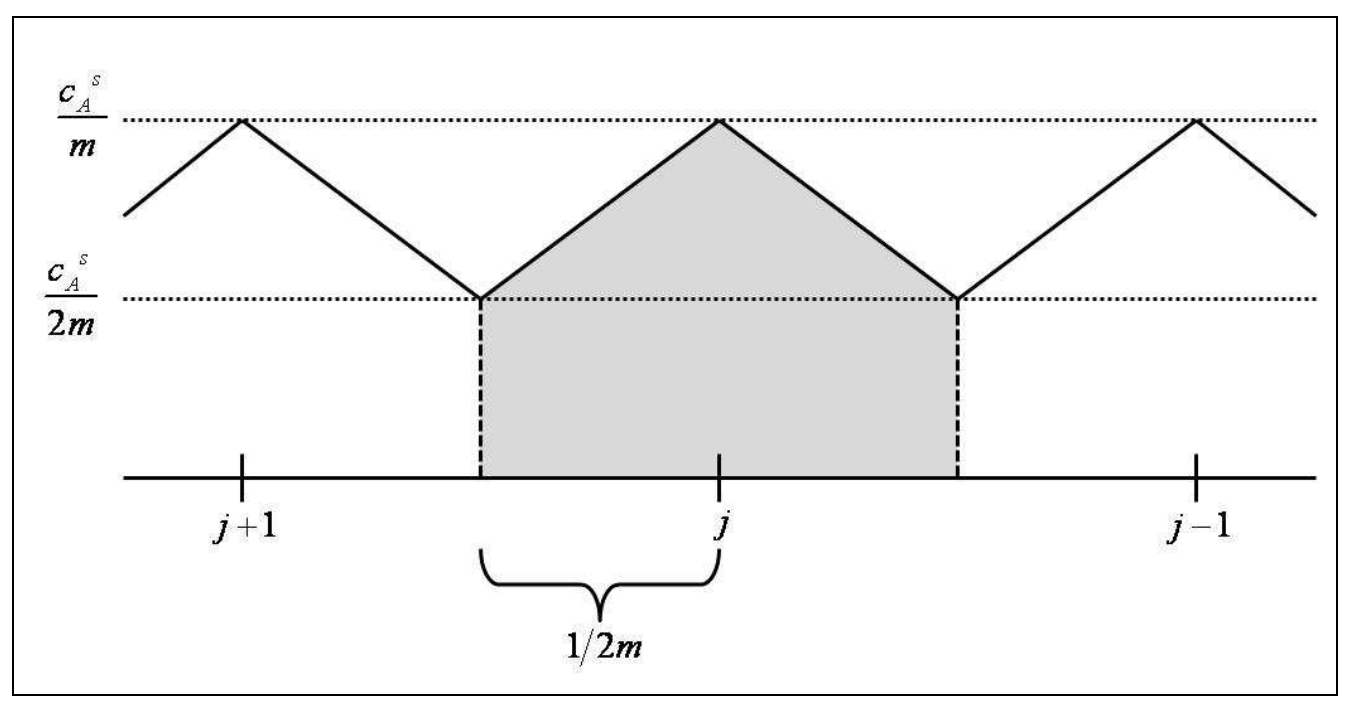

Figure 4: Small audit firms' revenues from providing audit services 


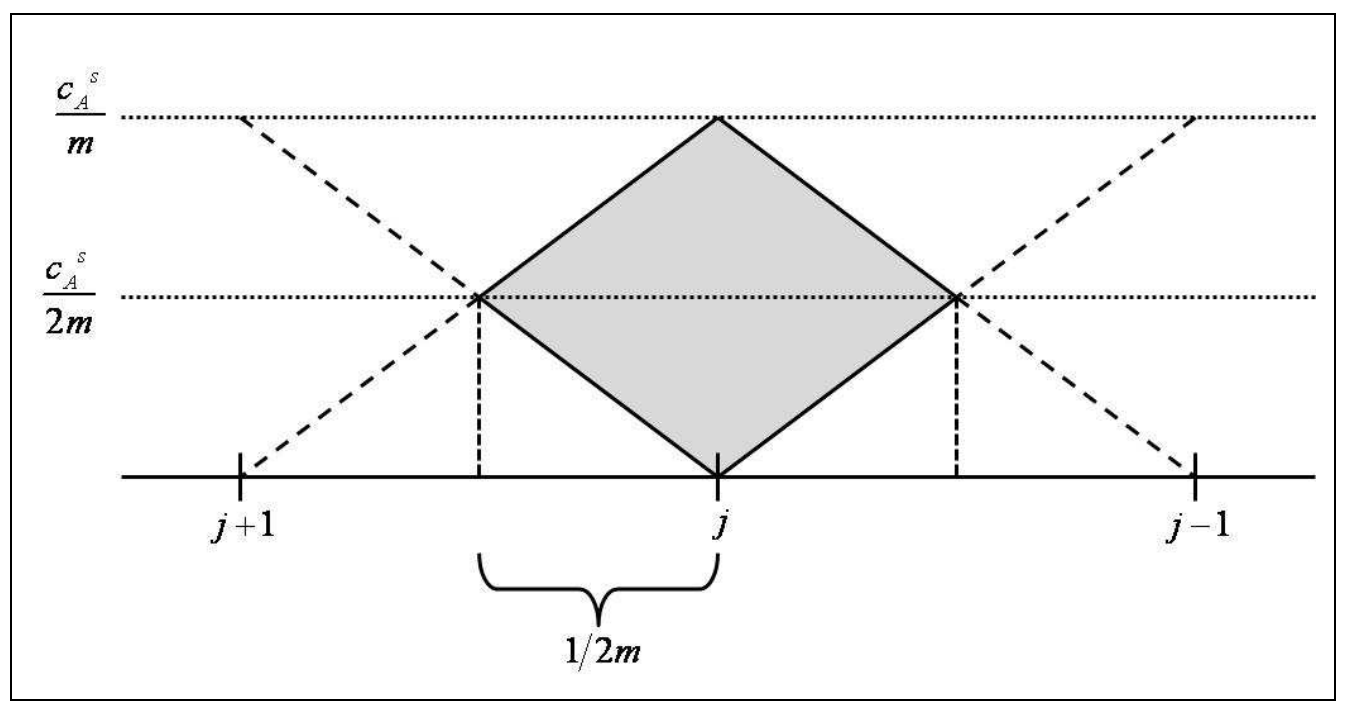

Figure 5: Small audit firms' profit contribution earned from providing audit services 


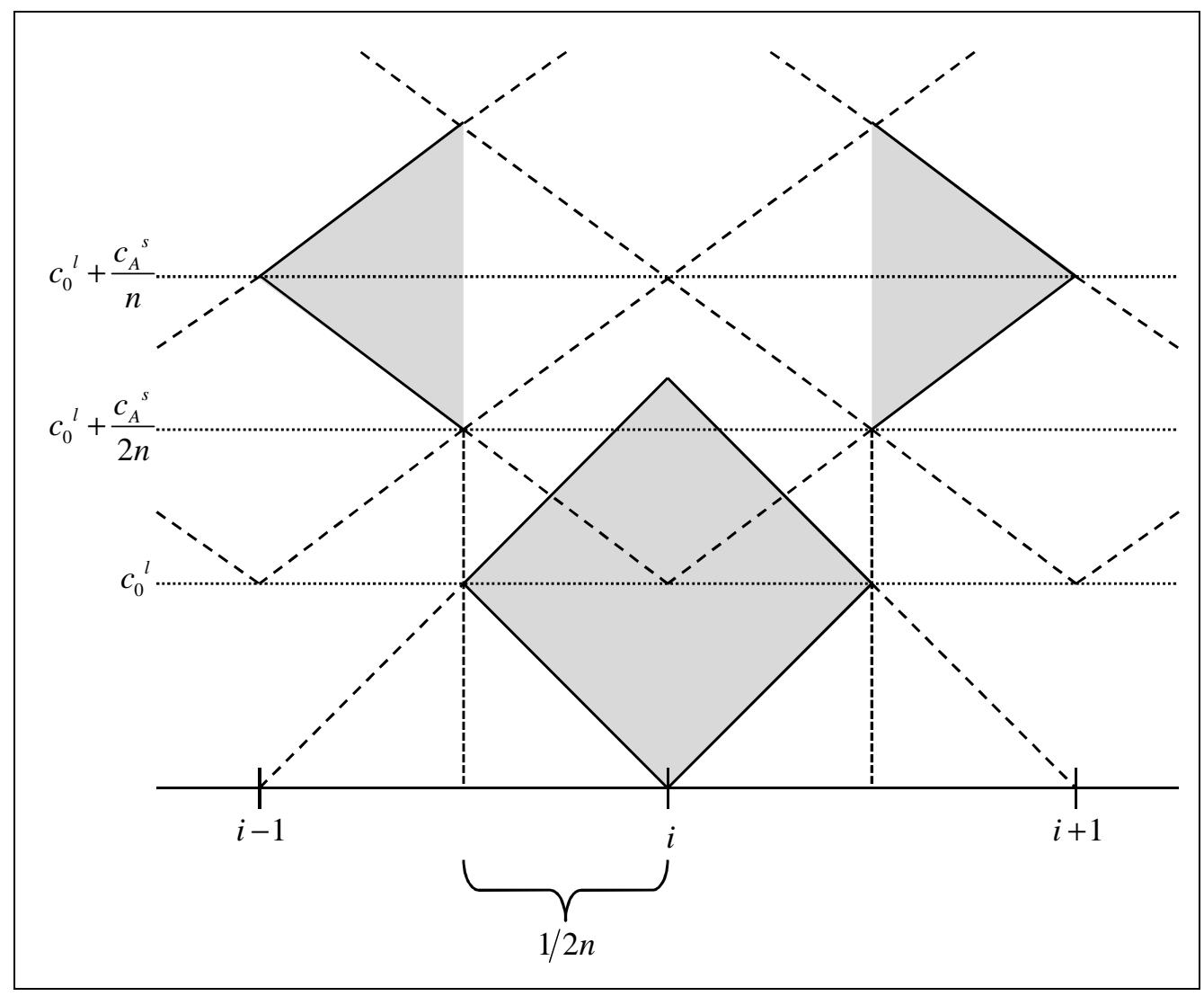

Figure 6: Large audit firms' profit contribution earned from providing audit and consulting services to various clients 


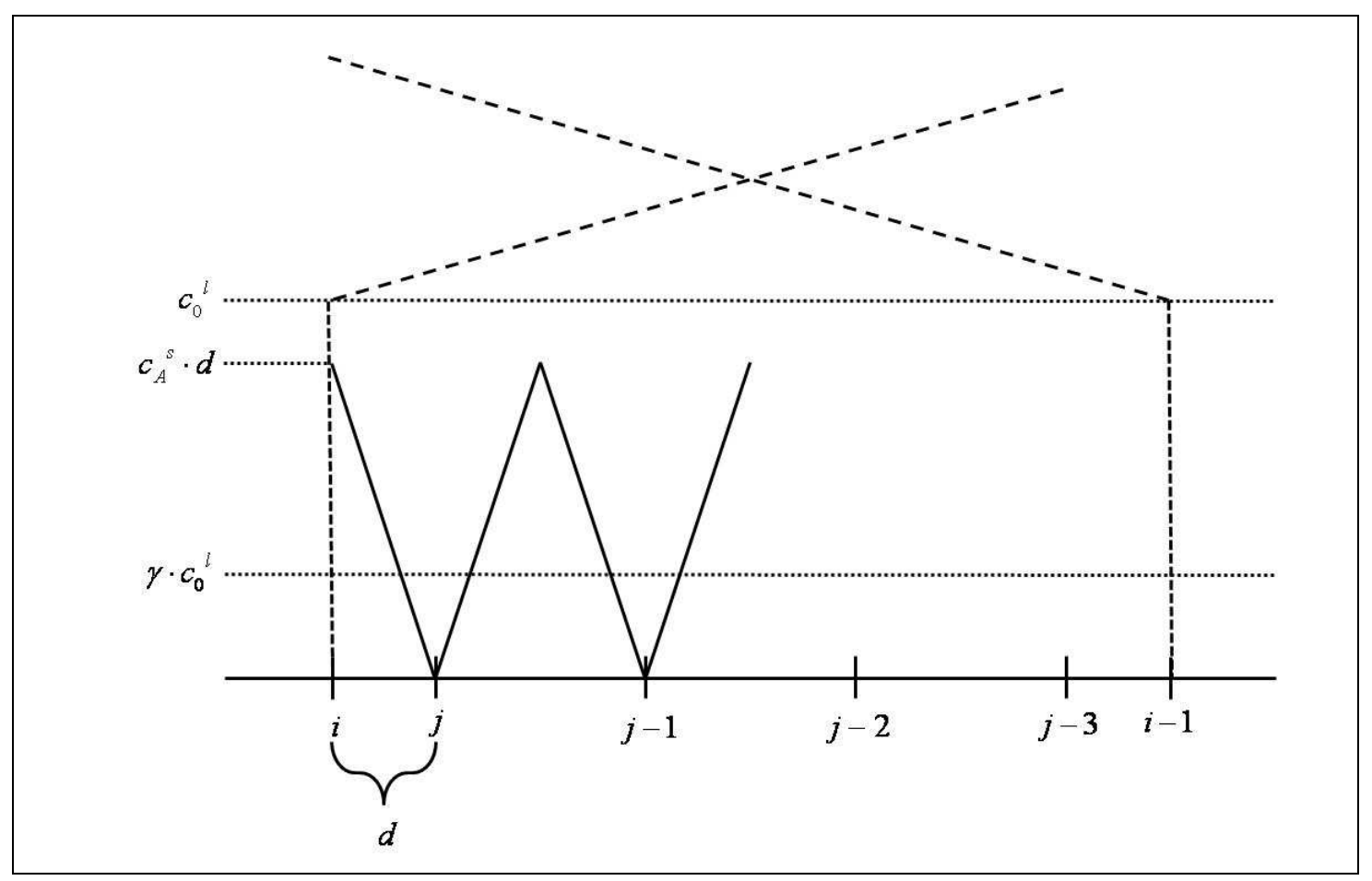

Figure 7: Cost structures of small and large audit firms if a prohibition on providing consulting services leads to separation of the audit markets 


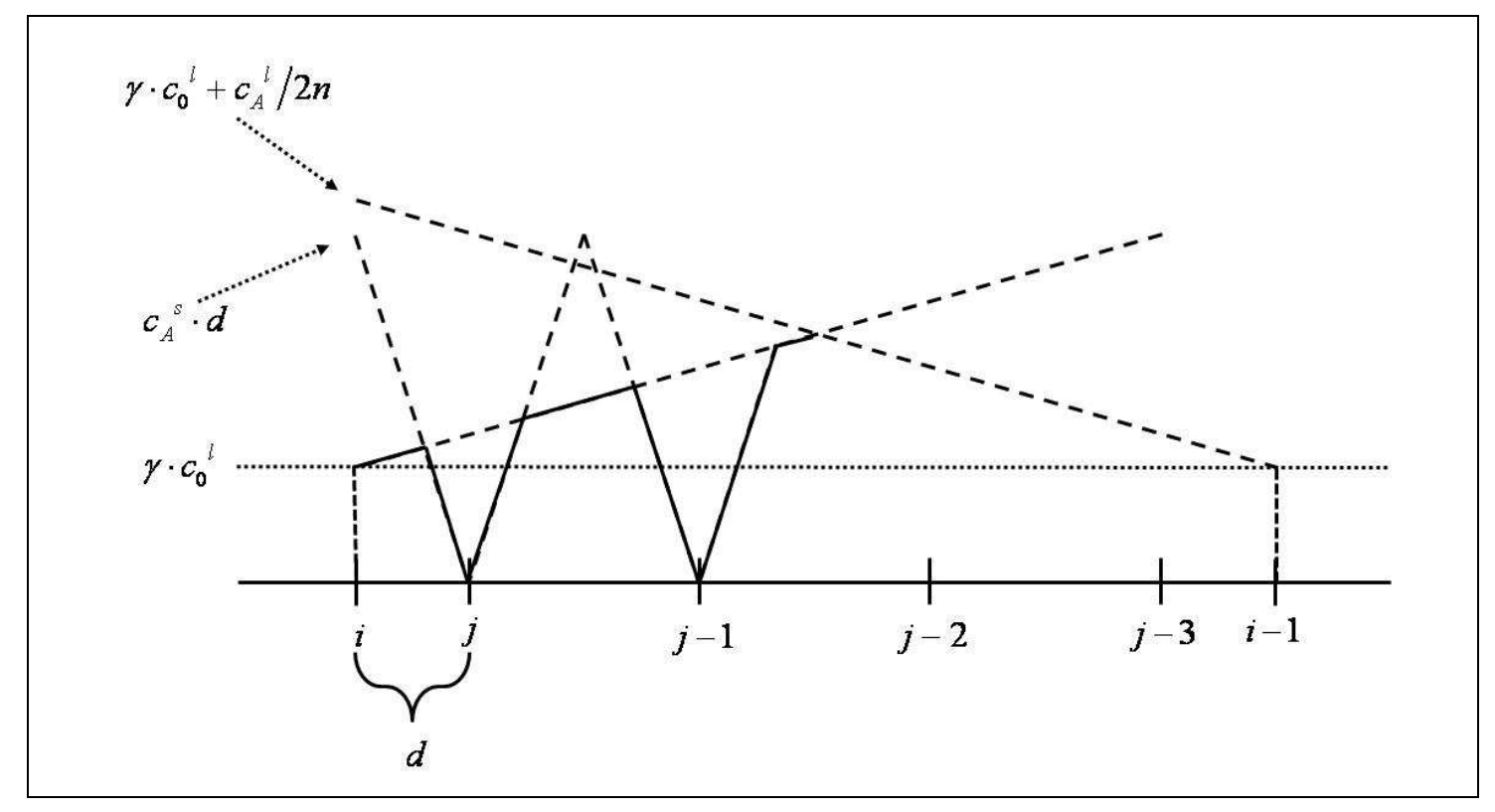

Figure 8: Cost structures of small and large audit firms 


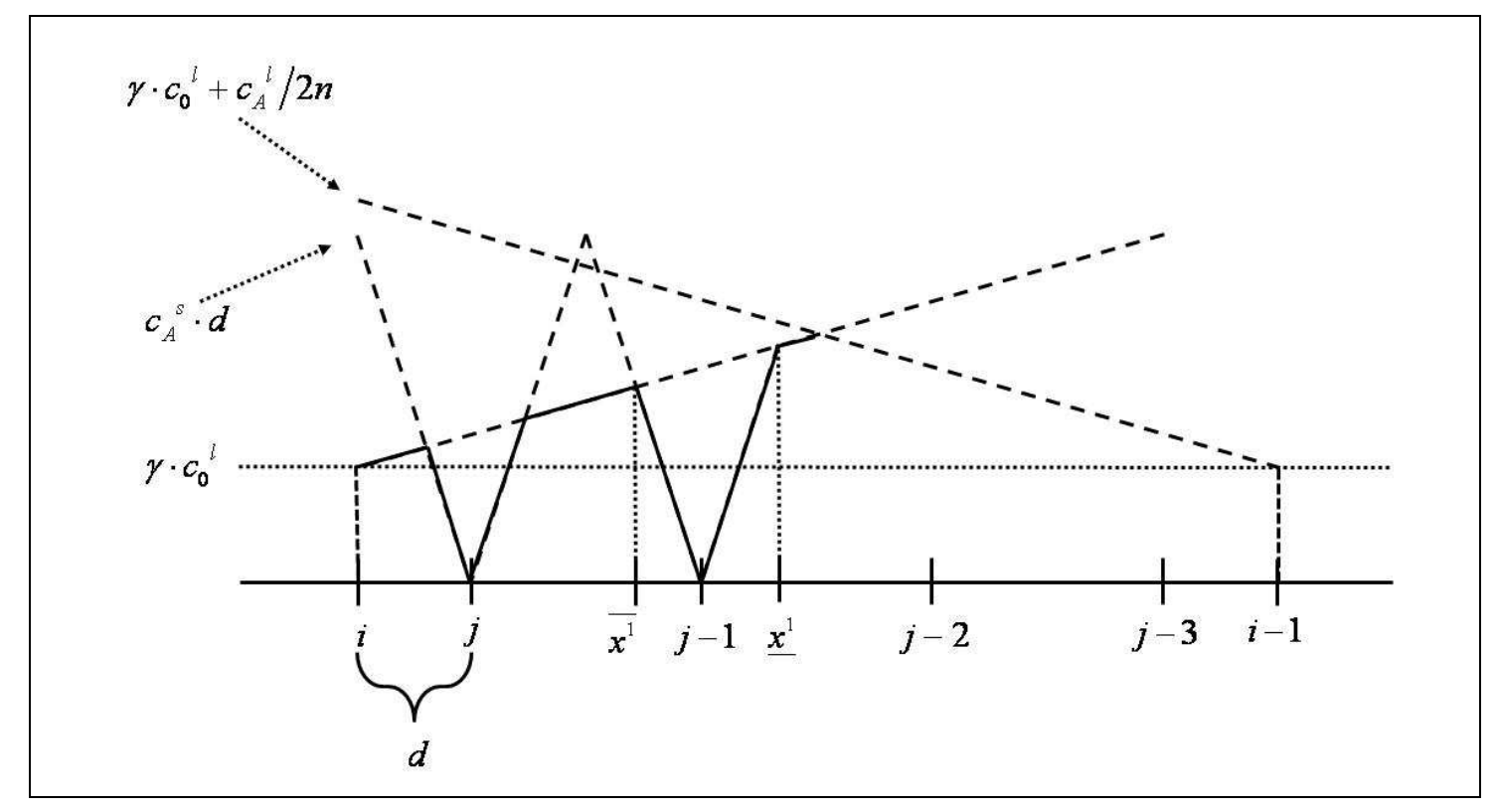

Figure 9: Contracting region of audit firm $j-t$ with $t=1$ 


\section{Literature}

Antle, R., Gordon, E., Narayanamoorthy, G., Zhou, L. (2006) The joint determination of audit fees, non-audit fees, and abnormal accruals. Review Quantitative Financial Accounting 27 (3): 235-266.

Barkess, L., Simnett, R. (1994) The provision of other services by auditors: Independence and pricing issues. Accounting and Business Research 24 (94): 99-108.

Beck, P. J., Frecka, T. J., Solomon, I. (1988) A model of the market for MAS and audit services: Knowledge spillovers and auditor-auditee bonding. Journal of Accounting Literature 7: 50-64.

Beck, P. J., Wu, M. G. H. (2006) Learning by doing and audit quality. Contemporary Accounting Research 23 (1): 1-30.

Bell, T. B., Landsman, W. R., Shackelford, D. A. (2001) Auditors' perceived business risk and audit fees: Analysis and evidence. Journal of Accounting Research 39 (1): 35-43.

Bigus, J., Zimmermann, R.-C. (2008) Non-audit fees, market leaders and concentration in the German audit market: A descriptive analysis. International Journal of Auditing 12 (3): 159-179.

Butterworth, S., Houghton, K. A. (1995) Auditor switching: The pricing of audit services. Journal of Business Finance \& Accounting 22 (3): 323-344.

Cairney, T. D., Young, G. R. (2006) Homogenous industries and auditor specialization: An indication of production economies. Auditing: A Journal of Practice \& Theory 25 (1): 49-67.

Chan, D. K. (1999) "Low balling" and efficiency in a two-period specialization model of auditing competition. Contemporary Accounting Research 16 (4): 609-642.

Chang, B.-G., Chen, Y.-S., Lee, C.-C. (2008) The association between continuing professional education and financial performance of public accounting firms. The International Journal of Human Resource Management 19 (9): 1720-1737.

Craswell, A. T. (1999) Does the provision of non-audit services impair independence? International Journal of Auditing 3 (1): 29-40.

Craswell, A. T., Francis, J. R. (1999) Pricing initial audit engagements: A test of competing theories. The Accounting Review 74 (2): 201-216.

Davis, L. R., Ricchiute, D. N., Trompeter, G. (1993) Audit effort, audit fees, and the provision of nonaudit services to audit clients. The Accounting Review 68 (1): 135-150.

DeAngelo, L. E. (1981) Auditor independence, "low balling", and disclosure regulation. Journal of Accounting and Economics 3 (2): 113-127.

DeBerg, C. L., Kaplan, S. E., Pany, K. (1991) An examination of some relationships between non-audit services and auditor change. Accounting Horizons 5 (1): 17-28.

Dopuch, N. (1988) Discussion comments of "An empirical analysis of the relationship between MAS involvement and auditor tenure: Implications for auditor independence". Journal of Accounting Literature 7: 85-91.

European Commission (2010) Audit policy: Lessons from the crisis. Green Paper. Brussels.

Ewert, R. (1990) Wirtschaftsprüfung und asymmetrische Information. Berlin, Heidelberg, Springer-Verlag.

Ewert, R., London Economics (2006) Study on the economic impact of auditors' liability regimes (MARKT/2005/24/F). Final report to EC-DG Internal Market and Services.

Ezzamel, M., Gwilliam, D. R., Holland, K. M. (1996) Some empirical evidence from publicly quoted UK companies on the relationship between the pricing of audit and non-audit services. Accounting and Business Research 27 (1): 3-16.

Frankel, R., Johnson, M., Nelson, K. (2002) The relation between auditors' fees for nonaudit services and earnings management. The Accounting Review 77 (Supplement): 71-105. 
General Accounting Office (2008) Continued concentration in audit market for large public companies does not call for immediate action.

Göggelmann, U. (2010) Kampf um den Kuchen. Financial Times Deutschland (13.10.2010): $23 \mathrm{f}$.

Graham, L. E. (1988) Discussion comments of "An empirical analysis of the relationship between MAS involvement and auditor tenure: Implications for auditor independence". Journal of Accounting Literature 7: 92-94.

Gullapalli, D. (2005) Audit fees are on rise as companies pony up: Payments for consulting and other services shrink, in big change from 2000. Wall Street Journal (25.03.2005): C3.

Hay, D., Knechel, R. W., Wong, N. (2006) Audit fees: A meta-analysis of the effect of supply and demand attributes. Contemporary Accounting Research 23 (1): 141-191.

Hogan, C. E., Jeter, D. C. (1999) Industry specialization by auditors. Auditing: A Journal of Practice \& Theory 18 (1): 1-17.

Hotelling, H. (1929) Stability in competition. Economic Journal 39 (153): 41-57.

Jenkins, J. G., Krawczyk, K. (2001) The influence of nonaudit services on perceptions of auditor independence. Journal of Applied Business Research 17 (3): 73-78.

Khurana, I. K., Raman, K. K. (2006) Do investors care about the auditor's economic dependence on the client? Contemporary Accounting Research 23 (4): 977-1016.

Knechel, R. W., Niemi, L., Sundgren, S. (2008) Determinants of auditor choice: Evidence from a small client market. International Journal of Auditing 12 (1): 65-88.

Köhler, A. G., Marten, K.-U., Ratzinger, N. V. S., Wagner, M. (2010) Prüfungshonorare in Deutschland - Determinanten und Implikationen. Zeitschrift für Betriebswirtschaft 80 (1): 5-29.

Larcker, D., Richardson, S. (2004) Fees paid to audit firms, accrual choices, and corporate governance. Journal of Accounting Research 42 (3): 625-658.

Lim, C. Y., Tan, H. T. (2008) Non-audit service fees and audit quality: The impact of auditor specialization. Journal of Accounting Research 46 (1): 199-246.

O'Keefe, T. B., Simunic, D. A., Stein, M. T. (1994) The production of audit services: Evidence from a major public accounting firm. Journal of Accounting Research 32 (2): 241-261.

o.V. (2009) Wirtschaftsprüfer bieten Dienste zu Kampfpreisen. Frankfurter Allgemeine Zeitung (16.09.2009): 16.

Palmrose, Z.-V. (1986) The effect of nonaudit services on the pricing of audit services: Further evidence. Journal of Accounting Research 24 (2): 405-411.

Petersen, K., Zwirner, C. (2008) Angabepflichten der Honoraraufwendungen für den Abschlussprüfer - Theoretische und empirische Betrachtung der Offenlegungserfordernisse zur Stärkung der Prüferunabhängigkeit. Die Wirtschaftsprüfung 61 (7): 279-290.

Quick, R., Sattler, M. (2011a) Beeinträchtigen Beratungsleistungen die Urteilsfreiheit des Abschlussprüfers? Zum Einfluss von Beratungshonoraren auf diskretionäre Periodenabgrenzungen. Zeitschrift für betriebswirtschaftliche Forschung 63 (6): 310343.

Quick, R., Sattler, M. (2011b) Das Erfordernis der Umsatzunabhängigkeit und die Konzentration auf dem deutschen Markt für Abschlussprüferleistungen. Zeitschrift für Betriebswirtschaft 81 (1): 61-98.

Quick, R., Warming-Rasmussen, B. (2009) Auditor independence and the provision of nonaudit services: Perceptions by German investors. International Journal of Auditing 13 (2): 141-162.

Raghunandan, K., Rama, D. V., Read, W. J. (2004) Local and regional audit firms and the market for SEC audits. Accounting Horizons 18 (4): 241-254. 
Salop, S. C. (1979) Monopolistic competition with outside goods. Bell Journal of Economics 10 (1): 141-156.

Schmalensee, R. (1978) Entry deterrence in the ready-to-eat breakfast cereal industry. The Bell Journal of Economics 9 (2): 305-327.

Simon, D. T. (1985) The audit services market: Additional empirical evidence. Auditing: A Journal of Practice \& Theory 5 (1): 71-78.

Simons, D., Zein, N. (2011) Audit market segmentation - The impact of mid-tier audit firms on competition. Working Paper, University of Mannheim.

Simunic, D. A. (1984) Auditing, consulting, and auditor independence. Journal of Accounting Research 22 (2): 679-702.

Stefani, U. (2006) Anbieterkonzentration bei Prüfungsmandaten börsennotierter Schweizer Aktiengesellschaften. Die Betriebswirtschaft 66 (2): 121-145.

Weil, J. (2004) Auditing firms get back to what they do best. Wall Street Journal (31.03.2004): C3.

Weil, J. (2005) In post-Enron world, accounting firms fight over the pieces. Wall Street Journal (18.03.2005): C1.

Whisenant, S., Sankaraguruswamy, S., Raghunandan, K. (2003) Evidence on the joint determination of audit and non-audit fees. Journal of Accounting Research 41 (4): 721-744.

Wu, M. G. H. (2006) An economic analysis of audit and nonaudit services: The trade-off between competition crossovers and knowledge spillovers. Contemporary Accounting Research 23 (2): 527-554. 